\title{
Swidden Transformations and Rural Livelihoods in Southeast Asia
}

\author{
R. A. Cramb - Carol J. Pierce Colfer • Wolfram Dressler • Pinkaew Laungaramsri • \\ Quang Trang Le • Elok Mulyoutami • Nancy L. Peluso • Reed L. Wadley
}

Published online: 28 May 2009

(C) Springer Science + Business Media, LLC 2009

\begin{abstract}
This paper explores the major interactions between the transformation of swidden farming and the pursuit of rural livelihoods in the uplands of Southeast Asia. The paper draws on selected literature, workshop reflections, and six case studies to describe the causal processes and livelihood consequences of swidden change. Householdlevel livelihood responses have included both the intensification and 'dis-intensification' of swidden land-use, the insertion of cash crops, the redeployment of household labour, and the taking on of broader (often non-rural) livelihood aspirations and strategies. At the community level there have been emerging institutional arrangements for management of land and forests, and varying degrees of participation in or resistance to government schemes and
\end{abstract}

R. A. Cramb $(\bowtie) \cdot$ W. Dressler

The University of Queensland,

Brisbane, Australia

e-mail: r.cramb@uq.edu.au

C. J. P. Colfer

Centre for International Forestry Research,

Bogor, Indonesia

P. Laungaramsri

Chiang Mai University,

Chiang Mai, Thailand

Q. T. Le

Center for Environment and Community Development,

Hanoi, Vietnam

E. Mulyoutami

World Agroforestry Centre,

Bogor, Indonesia

N. L. Peluso

University of California,

Berkeley, USA

R. L. Wadley

University of Missouri,

Columbia, USA programs. Swidden change has led to the loss and also the reassertion, realignment, and redefinition of cultures and identities, with important implications for access to resources. The impacts of these changes have been varied. Cash crops have often improved livelihoods but complete specialisation for the market increases vulnerability. Thus swidden can still provide an important safety net in the face of market fluctuations. Improved access to markets and social provision of education and health care have mostly improved the welfare of previously isolated groups. However, growing differences within and between communities in the course of swidden transformations can leave some groups marginalized and worse off. These processes of differentiation can be accentuated by heavy-handed state interventions based on swidden stereotypes. Nevertheless, communities have not passively accepted these pressures and have mobilized to protect their livelihood assets and strategies. Thus swidden farmers are not resisting appropriate and supportive forms of development. They are adopting new practices and engaging with markets, but in many situations swidden is still important to their livelihood strategies, providing resilience in the face of turbulent change. Active involvement of local people is essential in planning, implementing, monitoring and evaluating development and conservation programs in swidden lands. Positive market incentives and supportive government policies are better than standardised, top-down directives.

Keywords Agrarian change $\cdot$ Uplands · Livelihood strategies $\cdot$ Resource tenure $\cdot$ Food security $\cdot$ Agency

\section{Introduction}

Our aim in this article is to explore the multiple and recursive interactions between the transformation of swidden farming and the pursuit of rural livelihoods in the uplands of Southeast Asia. We draw on selected literature, 
workshop reflections based on field observations over many years, and six case studies to identify the major pathways of swidden change. Mertz et al. (2009a) deal with the definitions and types of swidden agriculture and Schmidt-Vogt et al. (2009) review the extent of change in swidden landscapes in the region. Our focus is on households and communities for whom swidden was historically "integral" to their livelihoods, social systems, and culture (Conklin 1957), but who through choice or necessity have partly or wholly transformed their swidden systems in recent decades (Rerkasem and Rerkasem 1995; Eder 1999; Padoch et al. 2007). Hence, to use the categories proposed by Conklin (1957) and Spencer (1966), our scope includes both "pioneer" or "linear-shift" systems and "established" or "cyclic-shift" systems (with varying crop-fallow rotations), whether these continue to be "integral" or, as is now almost everywhere the case, "partial", in the sense of being supplementary to other livelihood activities, or indeed no longer present in the livelihood system.

Ellis (2000) provides a framework for the analysis of changing and diversifying rural livelihoods that is useful for our purposes. A household or community is conceived as having a livelihood platform comprising various assets (natural, physical, human, financial, and social capital). Access to these assets is modified by prevailing social relations (kinship, gender, class, ethnicity), institutions (rules, customs, land tenure, markets), and organizations (local administration, state agencies, NGOs) in the context of exogenous trends (population growth, new technology, market expansion) and shocks (drought, forest fires, market collapse, civil unrest). These circumstances influence the choice of various livelihood strategies (intensification, commercialisation, migration, diversification) composed of an array of activities, including those based on natural resources (swidden, cash crops, forest collection) and those not based on natural resources (non-farm work, trade, remittances). The pursuit of these livelihood strategies by households and communities affects both livelihood security (food supply, income, seasonality, risk) and environmental sustainability (soil quality, forests, biodiversity). These strategies and outcomes in turn affect the asset base and access regimes on which future livelihood activities are constructed, typically leading to a process of differentiation within and between communities.

The transformation of swidden is clearly related in complex ways to all these aspects of changing upland livelihoods. In fact, in this view, the juxtaposition of "swidden" and "livelihoods" is somewhat artificial, as swidden farming is one element in these larger livelihood systems. The attractiveness of the livelihoods framework is that it highlights both the agency of swidden households and communities as they engage with and adapt to their changing circumstances, and the resultant diversity of strategies and outcomes in the context of what can appear at the macro-scale to be overwhelming "drivers of change"particularly demographic trends (Garrity et al. 1993; Mertz et al. 2009b), political-economic change (Fox et al. 2009), and major external shocks such as forest fires and war (Cramb 1998; Mayer 2003; Rambo 2005). We focus especially on the livelihood strategies devised to adapt to these larger trends and shocks, and their outcomes in terms of both livelihood security and changing access to resources at the local level. The environmental outcomes of these livelihood strategies are dealt with by Rerkasem et al. (2009), Ziegler et al. (2009), and Bruun et al. (2009).

The paper is organised as follows. In the first two sections we attempt to disentangle a variety of local-level causes and consequences of the widely observed decline in the importance of swidden in Southeast Asia as rural livelihoods are transformed. This brings out the complexity and contingency of the many processes involved and the variety of impacts on food security, other livelihood activities, household labour, local institutional arrangements, and cultural change. In the remainder of the paper we present six case studies that between them illustrate and support many of the different pathways of change identified (Fig. 1). The case studies were selected to represent a variety of settings - from Palawan in the Philippines (1), East and West Kalimantan in Indonesian Borneo (2 and 3), and Jambi Province in Sumatra (4), through to the central highlands of Vietnam (5) and the mountains of northern Thailand (6). A concluding section briefly summarises what we see as emerging lessons and implications.

\section{External Trends and Livelihood Strategies}

In this section we explore some of the proximate causes of a decline in swidden farming, that is, key external trends affecting the choice of livelihood strategies. These trends are roughly grouped under demographic change (local-level population growth, decline, and movement), the expansion of markets for commercial agriculture (smallholder and estate), and a complex of wider political, social and cultural trends affecting such crucial aspects of upland existence as the regulatory environment, education, religion, identity, and values. These changes are occurring simultaneously and interactively, over varying time horizons, driven by both endogenous and exogenous processes, hence they can only be sketched very imperfectly here.

\section{Demographic Change}

Demographic trends related to livelihood strategies include both population growth and population decline in a given locality, and associated in- and out-migration. Thus swid- 


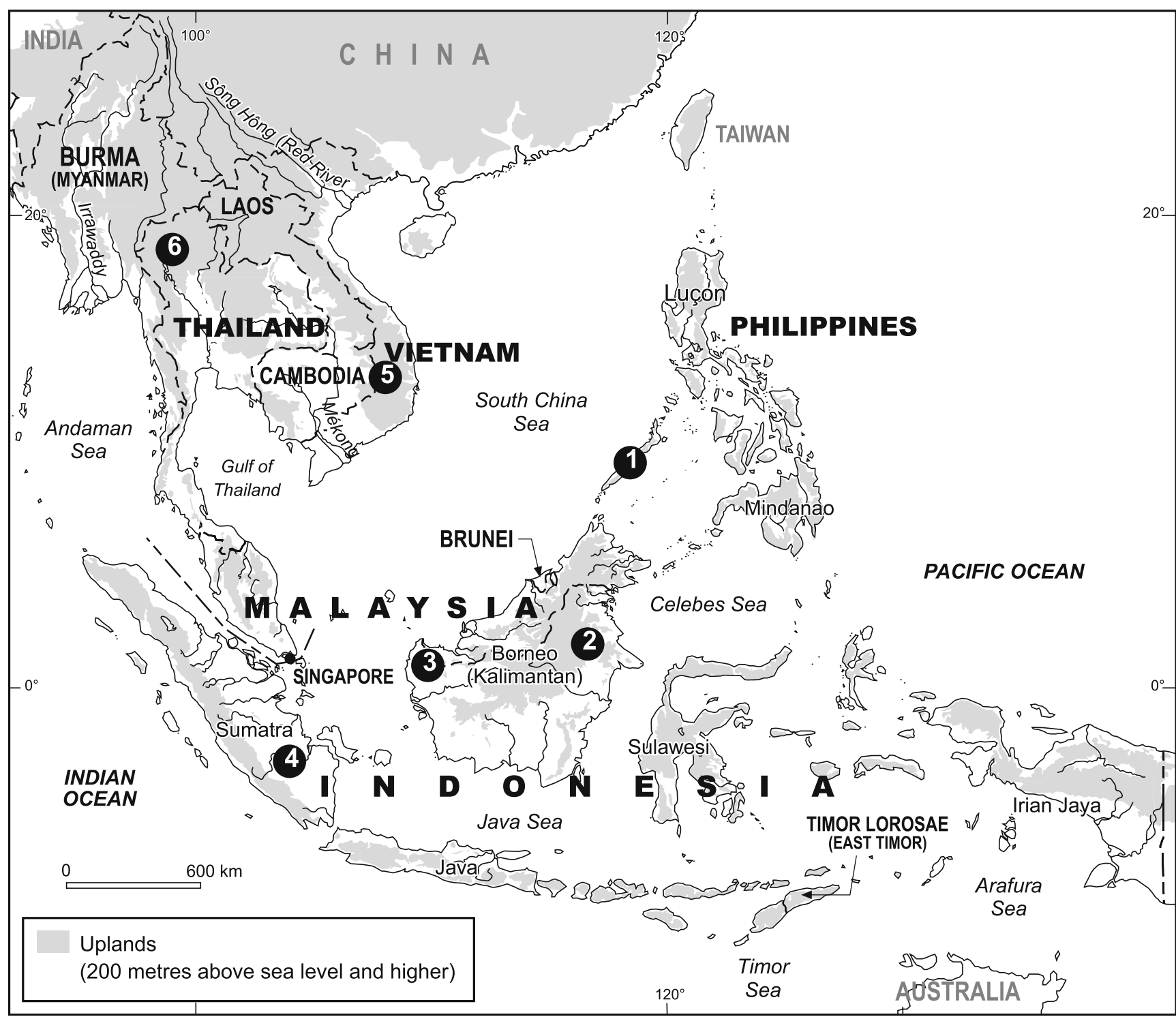

Fig. 1 Location of case studies in Southeast Asia (base map courtesy of Rodolphe De Koninck, ChATSEA Project, University of Montreal)

den farmers both respond to demographic trends (e.g., through intensification) and contribute to such trends (e.g., through migration).

Boserup's (1965) model of agrarian change is the starting point for an understanding of population-induced intensification of swidden agriculture. This is so whether the increased population pressure is due to natural increase in the original locality, as described by Roder (1997) for northern Laos, or, as appears to be the more common situation, where local populations are augmented through in-migration, both spontaneous and government-sponsored. This in-migration reduces the area available to each household for swiddening (as land is sold to or appropriated by the in-migrants) and thus induces a sequence of intensification to bush- and grass-fallow systems and ultimately to continuous cropping. Moreover, the in- migrants may bring with them lowland farming technologies, notably the use of the plough, which the local uplanders come to adopt.

There is clear evidence for this sort of transition in the Philippines, with largely spontaneous migration of Cebuano and other groups from densely populated regions into the "frontier" regions of Palawan (Case Study 1) and Mindanao (Eder 1999; Cramb and Culasero-Arellano 2003). Transmigration schemes in Indonesia provide examples of government-sponsored in-migration, resulting in a change in land use from swidden systems to more intensive, plough-based farming, though here it has been more common for the transmigrants to adopt short-fallow swidden practices as a survival strategy than for the locals to adopt intensive plough cultivation (Potter 1987; Masyhuri and Cramb 1995; Case Study 1). The movement of lowland Kinh into 
the Central Highlands of Vietnam has been both spontaneous and government-sponsored, with major implications for access to land and hence the practice of swidden by upland groups, inducing intensification and commercialisation on the one hand but also reversion to "pioneer" swidden on the other (Case Study 5).

Increased population in a given location can also occur due to movement of swiddeners to be closer to roads, markets, and public services, especially health and education (Case Study 2; Hansen and Mertz 2006). This is the reverse of the above-mentioned trend for lowlanders to migrate into upland swidden environments. In this case, uplanders migrate from more remote and isolated settings and thus add to population pressure in the more accessible locations, inducing an intensification of farming in the destination site and the reversion of swidden lands to forest or other land uses in the place of origin. Again, this can be the result of spontaneous movements (as with the Kenyah in Case Study 2) or government interventions involving various degrees of coercion (e.g., the resettlement of swiddeners from protected areas in Vietnam and Indonesia; resettlement of highland groups such as the H'mong in Laos; displacement due to dam construction in various countries; the reallocation of swidden lands for plantation development of oil palm and pulpwood in Malaysia and Indonesia).

There are many environments that are not amenable to the type of intensification Boserup outlines, due to poor soils, steep slopes, and intense rainfall (Cramb 2005). That is, they are less "elastic" in Brookfield's (1972) sense. Here, population growth, in the absence of other options, would result in shorter fallow periods, increased weed growth, soil degradation, declining yields, lower return to labour, and hence the demise of swidden. This is the stereotypical "downward spiral" that has often been predicted or assumed (Hatch 1982; Cramb 1988). However, in reality there are few examples where this has occurred, either in "original" locations or sites of in-migration. Rather, swiddeners generally respond first by pursuing other livelihood alternatives such as tree crops, off-farm work, or permanent outmigration, before reaching critical thresholds of land degradation. Roder (1997), however, reports that until the mid-1990s at least, swidden farmers in northern Laos did not have such alternatives, due to the lack of roads, markets, and technical support, hence increasing population pressure did lead to land degradation, especially in terms of weed infestation. In this circumstance a shortened fallow, while it may not decrease yield, requires increased effort for weeding, thereby reducing the returns to labour (Roder 1997). However, where farmers have access to modern inputs, this can be partly offset by the use of herbicides (Gerrits 1994).

Raintree and Warner (1986) have elaborated Boserup's theory of intensification, outlining potential agroforestry pathways that open up at different stages, such as enriched fallows in the forest- and bush-fallow stages and alley cropping in the short-fallow and annual cropping stages. They highlight that tree crops provide an alternative pathway of intensification, even at relatively low population densities and labour intensities. Mercer (2004) reviews evidence of such adoption pathways for a variety of agroforestry practices and settings. While enriched fallows and alley cropping have not been widely adopted (Roder 1997; Cramb 2000), swidden cultivators in Southeast Asia have frequently been motivated to incorporate tree crops such as rubber, coffee, and cocoa in their farming systems rather than push shifting cultivation to its ecological limits, thus necessarily moving beyond subsistence production to at least partial engagement with global markets (Case Studies 3, 4 and 5; Manivong and Cramb 2008).

Another intensification pathway available in some environments is the development of wet rice cultivation in inland valleys to provide higher and more stable yields (Seavoy 1973; Padoch et al. 1998). Many groups have long practised what Rambo (1998) terms "composite swidden systems", integrating both wet and dry rice fields, but in other cases demographic pressure can make new investment in wet rice cultivation more attractive. This may lead to the decline of swiddening in the surrounding hills. In some areas, especially with improvements in transportation, this form of intensification can occur at some distance from the village, with farmers moving back and forth between their place of residence in the hills and their wet rice farms downstream (Cramb 2007). The transfer of resources into wet rice farming is often given particular encouragement by central governments (and in some cases NGOs) keen to put an end to swidden and promote "settled" agriculture, as seen in Palawan (Case Study 1; Elmer and Shively 1998). However, while swidden farmers are typically open to this form of intensification if the returns to labour make it worthwhile, they will resist such initiatives where soil and water conditions are limiting, as for the Kenyah in Case Study 2 .

As indicated above, swidden may be disappearing, not because of population growth causing its transformation into more intensive cropping systems, but due to localised population decline. For reasons linked to economic and social change, swidden societies may experience outmigration, both temporary and permanent, leading to a reduction in the local resident population. Types of outmigration include school-aged children residing in boarding schools away from the village; young people seeking nonfarm work for months or years at time; young people moving out, marrying, and settling in urban locations; entire households moving out; and entire villages relocating (voluntarily or otherwise, as discussed above). These phenomena are of course interlinked, with schooling away 
from the village preparing the way for temporary and then permanent out-migration.

This demographic decline affects both the local demand for swidden production and the available labour force. On the one hand, fewer resident household-members means that decisions are made to curtail production, whether by reducing the area cleared and cultivated or by foregoing production for a season or two and drawing down stored supplies. On the other hand, the temporary or permanent absence of certain household members reduces the capacity to undertake full-scale production. The absence of school children depletes the available workforce at peak times such as planting and harvest. The absence of young male workers limits the capacity to clear the forest, thereby limiting the area cleared or restricting site selection to more recently farmed plots with young secondary growth that are more readily cleared by women and older household members. These changes reduce the total area cultivated in a village territory, as well as concentrating the cultivated area closer to the village centre, with consequent increase in the age of fallow vegetation at greater distance from the village. A further consequence of the absence of household members for extended periods, especially young people, is the loss of skills and local knowledge required for the practice of swidden agriculture. This in itself becomes a factor in the further decline of swidden.

\section{Market Expansion}

Expansion of commercial agriculture may take the form of smallholder cash crops or estate forms of production, again with varying degrees of local initiative and external coercion and with vastly different consequences for the rate of swidden change. Improved access to expanding global markets over a century or more has induced swidden farmers to scale back subsistence production in favour of smallholder commercial crops. This transition to "partial swiddening" typically occurs in a step-wise fashion as an economy develops (Barlow 1997; Barlow and Jayasurija 1986). Myint (1973) identifies two stages in the transition from subsistence production to production for the market. The first stage occurs when farmers use the larger proportion of their resources to produce for their own consumption, but use their spare land and labour to produce for the market, thereby minimising the risk involved. Swidden agricultural systems can provide "spare land" when population densities are sufficiently low that there is more than enough fallow land to meet the minimum fallowing requirements for sustained yield of food crops (Ruthenberg 1980). Swidden systems can also give rise to "spare labour" during the slack periods of the crop cycle, given the highly uneven nature of the labour profile (Eder 1977; Cramb 1989).
The second stage occurs when farmers allocate most of their resources to supplying the market and rely on purchasing commodities and services, with subsistence farming a spare-time activity. The shift is accelerated by the improvement of transportation and market infrastructure and the activities of market intermediaries, encouraging farmers to change from being "part-time" to "full-time" producers for the market. However, smallholders can remain at the semi-commercial stage for many decades, allowing temporary return to a subsistence economy when markets experience a downturn (Grijpstra 1978; Cramb 1993; Wadley and Mertz 2005). For example, Dove (1993) has highlighted how smallholder rubber in particular has provided swidden cultivators in Kalimantan with both ecological and economic adaptability for nearly a century. Case Study 5 graphically demonstrates the forced return to swidden in the face of the collapse of coffee prices in Vietnam's Central Highlands. Case Study 4 shows how some communities in Sumatra reserve swidden land specifically as a buffer or safety net for such market reversals. Case Study 2 likewise demonstrates the resilience provided by swidden agriculture in the face of major shocks to the livelihood system in the form of forest fires, commercial logging, and transmigration schemes.

The shift from first-stage to second-stage commercialization is not a smooth transition. When commodity prices are high farmers may reduce the size of their swiddens or skip a year or two, before deciding to cease swidden cultivation altogether. There is some evidence of a "ratchet effect" with successive booms of a cash crop (e.g., pepper, cocoa) inducing farmers to move progressively further away from reliance on swidden (Cramb 1993). At some point a threshold is passed (e.g., loss of viable seed stock or secondary growth too large for easy clearing by a depleted and inexperienced workforce) and swidden drops out of the household's livelihood portfolio altogether ( $\mathrm{Li} 2002$; Cramb 2007). Where access to land has been limited by government policy, such as the land allocation process in Laos which provides only three plots of land to swidden farmers, this accentuates the ratchet effect, inducing a more rapid shift to dependence on smallholder cash crops, in this case rubber (Ducourtieux et al. 2005; Thongmanivong and Fujita 2006; Manivong and Cramb 2008).

Different cash crops have different characteristics in terms of the degree to which they compete with swidden agriculture for land and labour. For example, rubber involves taking at least several hectares of land out of the swidden cycle, but the labour requirements for rubber can be readily worked around the peak periods for swidden. In the extreme, when rubber prices are low and subsistence needs take priority, rubber holdings can be left idle while all labour is switched back into swidden cultivation. On the other hand, pepper requires only half a hectare at most but 
makes big demands on labour throughout much of the swidden season, intensifying the competition for household labour (Cramb 1993). Crops also vary in the degree to which they are consonant with the long-term swidden cycle. Rubber is the classic case of a tree crop that can be treated effectively as an "enriched fallow" (so-called "jungle rubber" in Indonesia; Wibawa et al. 2005, though see Case Study 3 for a critique of this term). Old rubber trees can be cut and burned and the land returned to swidden cultivation much as if it had been under secondary forest. Pepper on the other hand is cultivated intensively with little prospect of the land reverting to swidden; likewise, continuous opium cultivation permanently deflects the forest succession and is a major reason for the linear-shift pattern of highland swiddeners such as the H'mong. Other crops (coffee, cocoa) have intermediate characteristics.

In some cases the growth in market demand in fact helps to offset the demise of swidden. Farmers in the immediate hinterland of growing urban markets (practising "peri-urban agriculture") can experience increased demand for swidden crops (upland rice and secondary crops) as well as forest foods (ferns, bamboo shoots, fruits, etc). This growth in demand can be partly caused by the very migration referred to above (e.g., urban Bidayuh who still return to acquire upland rice supplies from extended family in villages in the vicinity of Kuching, Sarawak). This can lead to the intensification of swidden production for the domestic market in these areas.

In contrast to smallholder cash crops, the expansion of commercial estates has led to the rapid and widespread demise of swidden agriculture. This expansion may incorporate swiddeners in various ways and to varying degrees. For example, the Sarawak Land Consolidation and Rehabilitation Authority (SALCRA) in Malaysia consolidates swidden lands for conversion to oil palm estates, the landholders being issued with titles and given employment on the estate, as well as receiving the proceeds from the sale of the fresh fruit bunches after costs are deducted (King 1986). However, much of their land is retained for both subsistence and smallholder cash cropping. In contrast, the Land Custody and Development Authority (LCDA) in Sarawak assembles extensive areas of swidden lands for inclusion in oil palm joint ventures with private plantation companies, leaving the landowners with little land for alternative pursuits, let alone for swidden, and relying on their shares in the joint venture for income (Fox et al. 2009). Nucleus estate and smallholder (NES) schemes for oil palm in Indonesia involve the allocation of extensive areas of land (much of which is former swidden land) to a central estate, with varying degrees of support for surrounding landholders to convert their lands to oil palm and supply the central mill (Zen et al. 2005; McCarthy and Cramb 2009).
In other cases swidden lands have been appropriated for private estate development with varying degrees of involvement of swidden farmers. For example, banana plantations in Mindanao in the Philippines involve longterm leasing of land and the employment of local farmers as plantation workers, while the allocation of land for private oil palm estates in Malaysian and Indonesian Borneo has in many cases ignored the customary land claims of swidden farmers (Cramb 2007; Fox et al. 2009; McCarthy and Cramb 2009). In all cases, whether the transformation is voluntary or coerced, the public and private investment in estate crops has accelerated the demise of swidden.

\section{Political, Social and Cultural Trends}

Increased political and regulatory control has been a major cause of the decline of swidden. This arises from the territorial policies of central governments, as reviewed by Peluso and Vandergeest (2001) and Fox et al. (2009). Regulations that attempt to discourage or proscribe swidden cultivation as a form of land use have been in place in some jurisdictions since colonial times. These regulations have taken different forms: (i) outright prohibition-a ban on swidden farming anywhere at any time; (ii) prohibition without a permit - giving government officers the discretion to decide if swidden farming should be allowed and to what extent; (iii) prohibition in certain classes of land - an attempt to restrict swidden (or any) farming to areas outside forest reserves and protected areas (often associated with resettlement, as mentioned above); (iv) tenure-related disincentives - including the non-recognition of customary land claims based on swidden, combined with the secure recognition of claims to land planted with commercial tree crops or "agroforestry". Superimposed on these are ideological forms of regulation whereby swidden farmers themselves are persuaded that their practices are backward and need to be abandoned if they are to be truly modern and developed (Dove 1983, 1986).

The emphasis here is on how this regulatory control is experienced (interpreted, accommodated, negotiated, and resisted) at the local level. In Case Study 1 it is argued that indigenous groups in Palawan internalized the negative perception of swidden held by both government and nongovernment actors, propelling their less-than-successful transition to "agroforestry" and wet rice agriculture. Case Study 3 highlights how the state-sponsored transformation of swidden to various forms of land schemes for rubber in West Kalimantan was linked in complex and sometimes violent ways to both ethnic and national identity and related questions of access. Case Study 6 shows how swidden farmers in northern Thailand reorganized their swidden system as a strategy to conform more closely to the perceptions of forest regulators concerning "appropriate" forms of land use. 
Socio-cultural causes of the decline of swidden are obviously important but harder to trace because they are so pervasive. These include the rise of modern education systems, conversion to mainstream religions, and exposure to mass media and consumer marketing, as well as the issues of ideology and identity just alluded to. Swidden in many traditional societies was as much a ritual undertaking as an economic one (Geddes 1954; Jensen 1974; Sather 1994; Wadley and Colfer 2004; Condominas 2009). For example, Uchibori writes: "Rice cultivation forms the core of the entire religious system of the Iban" (1984: 229). Conversion to mainstream religions thus undermines the ritual significance of swidden. This reduces the motivation to maintain swidden systems as well as eroding the "functional" aspects of a swidden-centred religious world view, such as the role of ritual experts in coordinating swidden activities and of traditional beliefs in protecting swidden fields from intrusion.

The education of young people in modern school systems away from the village not only reduces the availability of household labour for swiddens but prevents them from acquiring the necessary technical and ritual skills for undertaking swidden farming. At the same time it may expose them to development ideologies that regard swidden as backward and other forms of agriculture as modern and progressive. When combined with greater exposure to urban lifestyles and the influence of mass consumerism, the result is a change in attitudes and values that reduces the incentive of young people to engage in swidden farming.

A related socio-cultural issue has to do with changing gender roles. Swiddens, although worked on by both men and women, are in some societies primarily women's sphere of activity (Colfer 2008). Their work commitments are to swiddens and they see them as their own responsibility more than men's. This is particularly expressed in their custody of the household's rice varieties and their consequent control over planting and harvesting rituals and patterns, as well as their commitment to the crucial task of weeding (Geddes 1954; Chin 1985; Cramb 2007). With change in gender roles as a general consequence of modernisation, this crucial contribution of women to the maintenance of swidden is undermined. Often it is older women who hold on to the traditional rituals and practices even as the overall importance of swidden to the household economy declines.

\section{Interactions}

The various trends identified above typically act in combination to put pressure on swidden systems. In addition, the nature of such systems means that, beyond certain thresholds or tipping points, a declining trend becomes self-reinforcing. In economic terms this is largely due to the pervasive externalities involved in swidden farming. When one household opts out of the swidden cycle, temporarily or permanently, this increases the costs and risks for those remaining. This is most apparent in the case of pest control. A smaller cultivated area is more vulnerable to attack from avian and mammalian pests and yet there are fewer families available to combine their efforts in pest control. (However, Ole Mertz (pers. comm.) points out that a smaller area may be less susceptible to the build-up of diseases and insect pests.) Similarly, the size of labour-exchange groups is reduced, limiting the capacity to complete key tasks (planting, harvesting) in a timely fashion. There are also overhead costs, such as clearing a farm path to the group farming area or constructing perimeter fencing, which now fall to fewer families. Smaller numbers involved in swidden also undermine the conduct of group rituals, quite apart from the socio-cultural trends mentioned above. All these effects discourage families from continuing to practise swiddening (Cramb 2007).

A related point is that incorporating permanent crops such as rubber or cocoa means the opportunity cost of labour used for swiddens is higher. Whereas, in the past, farmers may have occupied a temporary farm hut in a distant swidden during the crop season, the need to work on permanent cash-crop holdings close to the village or roadside creates a need to move more frequently between locations. This increases the time required to complete a given task in the swidden and may result in less intensive crop maintenance (e.g., less weeding or pest control). Alternatively, it encourages the location of swiddens closer to the village or along a road and hence accentuates the shortening of the fallow period in this zone (Hansen and Mertz 2006). Again, these changes are likely to reduce further the returns to swidden farming and provide additional disincentive to its continued practice.

\section{Consequences for Rural Livelihoods}

The consequences for livelihood outcomes of the decline in swidden farming include changes in both livelihood security and environmental sustainability (Ellis 2000). Here we focus on the first set of outcomes, in particular, food security and other resource-based livelihood activities (though some of the case studies look at other dimensions of well-being). We also consider some of the dynamic consequences of changing livelihoods for the ways in which human and social capital are utilised.

\section{Livelihood Security}

The implications of the demise of swidden farming for food security and nutrition depend critically on the causes and 
nature of the demise. In situations where swidden farming is being restricted, without the provision of alternative livelihood options (e.g., in parts of Laos and Vietnam), food security declines. Less land for swidden means smaller farms and/or shorter fallow periods, both of which put downward pressure on household food output (e.g., Roder 1997, 2001; Ducourtieux et al. 2005; Lestrelin and Giordano 2007; Jakobsen et al. 2007; Manivong and Cramb 2008; Novellino and Dressler, 2009). Though the relationship between fallow period and yield has proved difficult to establish statistically (Mertz 2002; Mertz et al. 2008), there is little doubt that, below a critical fallow period, yields decline sharply, other things being equal (Ruthenberg 1980). The reason this does not readily appear in field data is that farmers increase weeding labour and/or the use of herbicides as fallow periods are shortened, thus partly offsetting the yield decline (Gerrits 1994; Jakobsen et al. 2007). In addition, land scarcity and reduced fallow periods often induce the cultivation of smaller farms which can be managed more intensively, thereby raising the yield (Cramb 2007). In many cases, farmers opt out of swidden altogether before crossing the critical threshold that would plunge them into unacceptably low yields and/ or returns to labour.

Where swidden is being restricted in favour of wet rice cultivation the possibility exists that total rice output may be maintained or increased. This will depend on the area of suitable land available and the yield potential for wet rice, hence the outcome is likely to vary within and between locations. Jakobsen et al. (2007) report that the expansion of wet rice area in an upland village in north-central Vietnam has not been sufficient to offset the enforced reduction in swidden area, leading to an overall reduction in rice output. In Case Study 1 in the Philippines, while some farmers with access to capital and better land have been able to increase food output, others have been forced to rely on a declining swidden resource with falling yields. Moreover, the shift from upland to lowland rice means a loss of secondary (non-rice) crops that are largely unique to the swidden system. Among the Saribas Iban in Sarawak these may account for as much as $40 \%$ of the value of output from a swidden field (Cramb 1985) and make an important contribution to family nutrition on a seasonal basis (e.g., leaves and tubers from intercropped cassava). Mertz and Christensen (1997) report similar findings for the Ulu Ai Iban, as do Colfer and Soedjito (2003) for East Kalimantan, and Colfer et al. (2000) for West Kalimantan.

Where swidden is being intensified along Boserupian lines, that is, being transformed into short-fallow or continuous cultivation as in much of the Philippines, it is again possible that output of the staple crop (rice, maize, sweet potato) may be maintained or increased on a household basis. This is especially likely if the intensifica- tion involves the use of modern inputs (high-yielding varieties, fertilizers, pesticides). In the Philippines, the spread of hybrid maize technology is occurring steadily in the uplands. While this is essentially a cash crop directed towards the livestock feed sector, there is likely to be a spillover into the production of traditional white maize varieties used primarily for subsistence. On the other hand, Eder (2006) notes a downward shift from upland rice to maize, sweet potato, and cassava as soils are depleted under more intensive systems.

The demise of swidden for whatever reason is likely to change the availability of fallow foods. Colfer and Soedjito (2003) report the relative importance of different sources of non-rice foods in Long Segar, East Kalimantan, during $1979-1980$ as follows: home-garden (14\%), swidden ricefield $(16 \%)$, forest $(26 \%)$, river $(23 \%)$, livestock $(2 \%)$, purchased (8\%), and unknown (7\%). Subsequent surveys indicated that most of the forest foods were obtained in bush- and forest-fallows rather than old-growth forests. Christensen (2002) has similar results for the Iban and Kelabit in Sarawak. Obviously these food sources are lost when fallow vegetation is transformed through intensification. This is also likely to be the case as fallow lands are taken out of the swidden cycle through restrictive land allocation, or simply because of spontaneous reduction in swidden cultivation for demographic, economic, or sociocultural reasons. The absence of a cropping phase reduces the degree to which fallow lands are planted with useful cultigens, as well as reducing the availability of edible fungi and other food items that emerge in the burned fields (Sather 1978). The increased growth of secondary forest also changes the relative availability of harvestable plant and animal products. For example, in Sarawak it was found that certain wild gingers were less abundant in older secondary forest, as were pigs and deer (the main sources of game meat), while monkeys and squirrels (considered agricultural pests) became more abundant (Chin 1985; Cramb 2007).

The change from swidden to perennial cash crops, while reducing subsistence production, can increase a household's ability to purchase food. There is some evidence from Sarawak that semi-commercialised systems with good road access are better able to deliver not only a secure supply of the staple food (rice), both self-produced and purchased, but also give households the capacity to purchase fresh meat and vegetables from mobile trading vans, possibly improving their diet. Of course, the increased dependence on cash crops makes households vulnerable to price downturns. So long as the swidden system can be scaled up again it provides a buffering role (Cramb 1993). However, where households have decided (or have no alternative but) to specialise in cash crop production, this valuable buffering role is lost and the vulnerability of the livelihood system is increased. This 
is brought out graphically in Case Study 5, showing how swidden farmers became overcommitted to coffee production in the Central Highlands of Vietnam and were plunged into poverty and debt when the market collapsed, severely limiting their livelihood options.

The loss of fallow lands, whether due to exclusion or transformation into more intensive land uses, means the loss of valuable non-food items that support a range of livelihood activities. These uses include fuelwood, construction materials, materials for making tools and weapons, mats, baskets, containers, medicines, and ritual and decorative uses (Cramb 2007: 92). Christensen (2002) found over 1,000 useful species in just two communities in Sarawak. Leaman et al. (1996) collected 200 species of medicinal plants in the Apo Kayan area of Kalimantan in 1989-1990. Most species (169) were wild, of which $10 \%$ were found only in primary forest, $40 \%$ in mature secondary forest, $25 \%$ in young secondary forest, and $25 \%$ in recently disturbed sites (i.e., fallowed rice-fields and along paths). The loss of these resources has direct and indirect economic implications; it can mean a loss of income where the items were previously sold, or increased expenditure on purchased household items where these can no longer be self-produced. In addition, the loss of fallow resources further undermines swidden-based cultures and lifestyles, including local knowledge of the fallow ecology.

On the other hand, restrictions on swidden cultivation without providing viable economic alternatives places households under increasing pressure to exploit the surrounding forest, primary and secondary, for timber and nontimber forest products. For example, Eder (2006) reports greatly increased collection pressure on rattan and Manila copal (Agathis resin) in Palawan. See also Novellino and Dressler (2009) for the Philippines. Fujita and Phengsopha (2008) report similar results for Laos, and Jakobsen et al. (2007) for Vietnam. As described in Case Study 5, restricted access to land in Vietnam's Central Highlands due to in-migration (combined with the above-mentioned coffee crisis) has pushed poorer local farmers back into the forest to survive.

\section{Human and Social Capital}

Human capital refers to the available time, skills, and workroles of household members. Swidden systems provide productive employment for household members, at least on a par with cash crops (Cramb 1989) and low-paid urban or plantation work (Nielsen et al. 2006). Moreover, swidden employs the household's workforce in particular ways, with seasonal peaks and troughs, distinctive inputs according to age and gender, periodic exchange of labour between households, and the utilisation and reinforcement of agricultural and ecological knowledge and skills specific to the swidden cycle (Cramb 1989; Colfer et al. 1997). Among many groups, such as the Kenyah of East Kalimantan, swidden is in fact primarily a female responsibility and central to women's sense of identity and purpose (Colfer 2008).

The demise of swidden involves the redeployment of the household's labour in other activities. These may or may not utilise the time and skills of different household members to the same degree. Pepper cultivation does in fact offer a variety of tasks that can be undertaken skilfully by men and women, young and old, even the elderly confined to the house (sorting and drying pepper berries). On the other hand, oil palm cultivation offers less variety in the nature of the tasks involved, with mature holdings mainly requiring the strenuous work of harvesting. Other crops and livelihood activities utilise household labour in different ways. For example, rubber tapping is undertaken by men and women, though not usually by the elderly.

Where swidden is maintained in a more specialized and intensive form, partly to meet market demand in the region, this can imply a particular role for some members of the household, notably older women, that differs from the livelihood strategies of other household members who concentrate on cash crops or off-farm work. Eder (2006) describes such a development in Palawan, and anecdotal evidence exists for the Bidayuh in the hinterland of Kuching - the rapidly growing urban centre of Sarawak, Malaysia.

The demise of swidden means changes in customary institutions governing the use of land and the organization of labour-part of the social capital that has helped maintain the viability of swidden communities (Sather 1990). With households working on their own permanent plots there is no need for an annual farm meeting to decide on the location and timing of farming activities or the collective allocation of swidden plots (Cramb 2007). Nor is there any need for collective rituals to obtain favourable farming omens or placate earth and forest spirits (Dove 1988; Sather 1994). There is also a decline in the use of labour exchange, particularly if swidden farming is replaced with perennial cash crops. These contribute to a decline in social and cultural cohesion and sense of identity.

Swidden lands may have been owned individually or held by the descent group or the village community and apportioned annually, but in both situations the community plays an important governing role. The transition to permanent farming, whether wet rice cultivation or perennial cash crops, typically involves increased individualisation of land tenure and the weakening of community governance, as with rubber planting in West Kalimantan and Jambi (Case Studies 3 and 4), the transition to wet rice among the Tara'n Dayak in West Kalimantan (Padoch et al. 1998), and with a general shift to cash crops among the 
Bidayuh of Sarawak (Gerrits 1994). This can create a situation of unequal access to land, and even the emergence of a landless class, as for example among former swidden farmers who have taken on cocoa production in Central Sulawesi (Li 2002). On the other hand, in Jambi (Case Study 4) community institutions were developed to maintain control over a portion of swidden fallow lands as a social safety net. Among some Iban longhouse-communities in Sarawak, where swidden decline has resulted in extensive areas of unused fallow lands, the community has reasserted its authority over the disposition of these lands, negotiating with government land development agencies on behalf of all community members (Cramb 2007).

The reduced utilization of swidden lands can weaken land rights in the eyes of the state (Scott 1998). It has already been noted that lack of state-recognised land rights can be a cause of swidden decline. For example, the state may move to exclude swiddeners from their fallow lands, whether for forest or habitat protection (as in Vietnam and Laos) or to reallocate the land to private estate development (as in Malaysia and Indonesia). However, the loss of land rights can also be a consequence of the decline of swidden as governments invoke the widely claimed (and widely contested) principle that "idle land" should revert to the state. In any case, it becomes harder in practice to demonstrate to outsiders the validity of customary claims to land after long periods without cultivation.

Other social and cultural consequences of swidden decline are difficult to disentangle from the wider transformations underway as a result of in-migration, modern education, religious conversion, mass marketing, communication technologies, individual mobility, and political and other propaganda. However, the demise of swidden is undoubtedly associated with the loss of an elaborate cultural repertoire associated with the beliefs and rituals centring on the swidden cycle, as well as the loss of the material culture that underpins swidden activities. This can undermine the sense of identity and accelerate the marginalization of upland groups, who lose confidence in their culture and experience social fragmentation and decline. As noted earlier, women's sense of identity and purpose may be particularly affected. Traditional conceptions of leadership and success associated with swidden may be undermined in favour of externally defined concepts of "modernization" and "development". This is related to the loss of self-sufficiency and the increased importance of external linkages and dependencies (market, bureaucratic, and political).

At the same time we sometimes see the emergence of new social and cultural forms and redefinitions of local identity. For example, Dayaks in Sarawak have adapted some of their farming rituals to pepper cultivation and the successful pepper farmer is now seen as an outstanding individual in the community, worthy of respect and emulation, just as the successful rice farmer was traditionally lauded. Both men and women contribute significantly to this activity. In Palawan, with indigenous and migrant groups intermingling and swidden giving way to more intensive land uses, Eder (2006) reports the emergence of a new identity framed around locality and environmental consciousness rather than any one language or cultural tradition. However, Case Study 3 shows how the transformation of swidden landscapes in West Kalimantan was associated with state policies that resulted in the sharpening of ethnic identities and the "racialisation" of territories, with major implications for who gains and loses access to land resources.

\section{Case Studies}

As argued in the preceding sections, the transformation of swidden livelihoods in Southeast Asia is not a uniform process in space or time. The agency of local landholders and communities is evident in the variety of responses to the external "drivers" of change, both within and between localities. Much of the evidence for this argument is found in the six case studies that follow. These cases illustrate the impacts of different systems of governance as well as widely contrasting demographic, economic, socio-cultural, and historical contexts. Nevertheless, they are not to be taken as "representative" of the jurisdictions in which they are located. These are "cases" in the sense of particular local "outworkings" of underlying or more general processes of change. Another selection of cases in the same jurisdictions may well have highlighted different outcomes, but would still have served to demonstrate the nature of the transformations underway.

Case 1: Migration, Swidden Transformation, and Differentiation in Palawan, Philippines

The Tagbanua in Barangay Cabayugan, an area $3 \mathrm{~h}$ north of Puerto Princesa City in central Palawan, are a sub-coastal, swidden people who have relied on upland rice and nontimber forest products for centuries; some pursue seasonal fishing, shallow diving, and the collection of crustaceans; and most, if not all, eventually have combined these activities with some form of wage-based employment (Dressler 2008). From the 1950s until today, lowland migrants have departed from resource-scarce and violenceprone parts of the Philippines such as Luzon and the Visayas to settle at Cabayugan. Most migrants considered Palawan to be abundant in resources and peaceful, an exception to many other Philippine islands. The original migrant population was relatively homogeneous; most were from two extended families. By 2001 the population of Cabayugan's three main sitios (hamlets) had diversified into 13 different migrant 
ethnicities, easily out-numbering Tagbanua. Of 157 households surveyed, $69 \%$ were migrant households, with the remaining 31\% Tagbanua households (including some 'mixed' households that claimed Tagbanua identity).

Once settled, migrants and Tagbanua often assisted one another to clear forest and prepare swiddens in rotation (the bayanihan system), harvest wild pigs, and share food without direct monetary exchange. In time, however, reciprocal work relations were succeeded by commodity relations and social and economic differentiation. With pioneer migrants settled and other migrants following in the late 1970s, gradual changes in trade relations and the conversion of forest into farmland unfolded in Cabayugan. In sequence, migrants cleared forest for swidden by hiring Tagbanua labour for felling, clearing, sowing seeds, weeding, and harvesting rice on plots eventually converted into wet rice or paddy fields. Flat alluvial lands flanking the Cabayugan River were well-suited for paddy fields, which were soon expanded and yielded surplus rice. As Tagbanua cleared forests and produced goods for migrants, production and exchange relations began to support fledgling commodity markets through which trade relations became increasingly asymmetrical. New social divisions of labour thus arose as Tagbanua redirected time to produce commodities for local markets controlled by migrants (Dressler 2006).

Migrants came to control more and more productive resources in Cabayugan. They claimed flat lands through seizure or purchase, converted swiddens into paddy fields, and often took out private title. With secure title, a few wealthier migrants easily expanded paddy rice, while Tagbanua cultivated swidden on plots held in usufruct. As a result, the social, political and economic positions of each group became increasingly differentiated. While most migrants expanded their paddy fields with advanced farming technology (e.g., high-yielding seeds, hand tractors, and water pumps), or were linked in paddy rice production networks, few Tagbanua cultivated paddy rice with great success. The ability of pioneer migrants to claim flat, productive lands and then occasionally register that land with the Bureau of Lands, afforded them security to produce and sell surplus rice in local and city markets. Profits were reinvested in paddy rice production, their homestead, and their children's education, which supported their control over paddy farming. The ability of migrants to claim productive resources, exploit trade relations, and maintain wealth continues to drive difference in terms of both ethnicity and agriculture in Cabayugan today.

These processes also gradually led to differentiation within the Tagbanua community. The socio-political and economic connections of ginoo ("high blood") Tagbanua with migrants have given rise to an emergent "wealthier" class of Tagbanua farmers who maintain their networks and wealth often by excluding others from tapping them.
Because these wealthier Tagbanua have long-established ties with highly successful paddy rice farmers, they have had the opportunity to borrow capital—such as carabao, ploughs, and tillers - to begin and sustain paddy rice farming on former swidden fields, or on paddy lands they have gained access to through share-cropping arrangements with prominent migrants. Meanwhile, poorer Tagbanua with limited access to these networks have difficulty accessing the increasingly scarce land and capital necessary for intensification. As the networks between "wealthier" Tagbanua and migrants become consolidated, poorer Tagbanua (and poorer migrants) have continued to rely on swidden as the mainstay of their livelihoods.

The recent influx of NGO-led conservation initiatives in central Palawan has exacerbated the rise of within-group differentiation in Cabayugan. Many NGOs and government officials have directed the behaviour of the few moderately wealthy Tagbanua households toward intensifying swidden agriculture. NGOs now ally themselves with prominent Tagbanua to ensure that the latter internalise and reproduce an "ecological ethic"-one that suggests swidden is environmentally destructive. As a result, many Tagbanua cite the concerns of NGOs over swidden as one reason for sedentarizing production through agroforestry plots and, where possible, investments in paddy rice cultivation. This process and its outcomes are justified by recent evidence of reduced fallows, lower rice yields, and the application of pesticides and fertilizers in swiddens (Dressler and Turner 2008).

While wealthier Tagbanua tend not to abandon swidden entirely, since it still serves as a subsistence safety net, in compliance with NGO and government demands for permanent cultivation they have now begun to convert their swidden lands into "agroforestry" plots and then (given suitably flat land) into paddy rice fields. However, because of poor tending and pruning, fields that have been planted with tree crops are unlikely to generate significant extra income. In the meantime, poorer Tagbanua households have continued to clear forest-fallow plots for upland rice in less accessible locations. This recent process of within-group differentiation has now become very apparent as the poorer Tagbanua are "locked into" swidden production due to limited political networks and access to productive resources. In these circumstances, poorer Tagbauna continue to rely on swidden as the basis of their subsistence and stress that they are unlikely to abandon swidden, as wealthier Tagbanua have done, even if they take on newer, more productive forms of agriculture.

Case 2: Resilience of Swidden Farming in a Radically Transformed Landscape in East Kalimantan, Indonesia

In 1962, the Uma' Jalan, a sub-group of Kenyah Dayak swidden cultivators from the very centre of Borneo, found 
themselves in conflict over religion, resources, and aspirations for the future. A small group made the long trek through primary forest to a more accessible location along the Telen River, establishing the new community of Long Segar, which by 1980 had a population of about 1,000. Swidden cultivation continued to be an integral part of their way of life in this new setting. ${ }^{1}$

The early 1970s brought a major El Niño drought (1972) and an American timber concession to the region. The people gained access to rice hullers and chainsaws, which reduced life's drudgery. They also gained markets for their upland rice, expanding their swidden fields to meet the new demand. In 1975, the Government "gave" each family 3 ha and various inputs as part of a "resettlement" scheme. Although the intention was to convert the Uma' Jalan to paddy rice cultivation, they had no way to control irrigation water. Hence they continued to practice swidden agriculture.

A much more severe El Niño event occurred in 1983, resulting in a devastating fire that burnt over $50 \%$ of Long Segar's forest. During the drought, the people survived by eating cassava and panning for gold. The next year rats invaded. Small groups of people left Long Segar to establish other communities in Tanah Merah and Karangmumus, close to the provincial capital, in search of easier access to medicine, schooling, and markets. In both new sites, the people continued to cultivate swiddens but added more cash crops (e.g., bananas, rambutan).

By 1985, the Government had established a huge transmigration project just $2 \mathrm{~h}$ upriver from Long Segar (causing the population density in the district to jump from $2 / \mathrm{km}^{2}$ to $65 / \mathrm{km}^{2}$ ). Some Long Segar inhabitants joined the transmigration project, which was designed to have a nucleus estate with smallholder tree crops. Initially, however, transmigrants were given only 1.0 to 1.25 ha (for home garden and food crops). By the third year, in order to survive, most newcomers had turned (at least temporarily) to swiddening, as the soils were not suitable for permanent agriculture.

In 1990, the Government and timber industry established an industrial timber plantation (HTI), primarily of Acacia mangium, about $2 \mathrm{~h}$ downriver from Long Segar. Around 300 transmigrant families, who only received 0.25 ha of land, were brought in as labour for the plantation. Meanwhile both the HTI and the Transmigration Program worked with Uma' Jalan leaders of the newly founded, nearby Kilo Enam settlement to establish a viable agroforestry system, combining swidden with commercial crops (rubber, pepper, acacia). Those participating in this scheme soon encountered a new problem as they experimentally reduced their fallow periods: invasion by Imperata grasses.

\footnotetext{
${ }^{1}$ This case study draws on material presented in more detail in Colfer et al. (1997), Colfer and Dudley (1993), and Colfer (2008)
}

In 1997-1998, just as the rubber was beginning to yield, the most devastating El Niño struck and their entire territory was burned to the ground. The most vulnerable areas were the commercial tree crops (acacia and rubber), which were totally obliterated. This year was followed by an even more devastating rat invasion, and all the land was soon covered in dense vines. Still the people continued to produce rice on their swiddens, supplementing it with salvage logging in the burned forest.

By 2000, Government attention had turned to oil palm. Government officials and industry personnel worked together to persuade local communities to accept this crop. Long Segar inhabitants saw what happened to a nearby community that had made an agreement with an oil palm company. The company cleared their land, sold the timber, and immediately declared bankruptcy, leaving the community with a "nursery" of tightly packed polythene bags full of 4-m high oil palm plants and a large cleared area of no immediate use. Long Segar inhabitants also recognized that acceptance of oil palm would mean a shift from independent farmers to wage workers. The people continued to reject it, to farm their swiddens, to supplement their incomes with wage labour, and to experiment with cash crops.

These people have witnessed and chosen momentous changes in their lives. Women, who have been the mainstay of this swidden system, have gained access to and enthusiastically embraced family planning. They have also begun to take advantage of wage labour opportunities from time to time; and they have embraced formal education. The men, whose work and shopping sojourns in Malaysian Borneo had often lasted a year or more, now make much shorter provincial trips to earn money, and many goods are available nearby. Families have more money, and the children go to school. Formal educational levels have risen dramatically.

Health has improved. Access to the formal medical system is easier and child mortality has reduced dramatically. Nutrition, despite the serious reduction in access to forest foods due to environmental degradation, has improved, with people substituting garden produce for forest foods and changing their dietary balance away from staples and toward more diverse foods. Oddly, the proportion of purchased food (around 6\%) did not change significantly from 1979-1980 to 2001.

But not all changes have been advantageous. In Long Segar and its offshoot communities, social problems have increased (drinking, drugs, prostitution, theft). There is more conflict (over ethnicity, rights, resources), and there is less security of access to resources. Their territory has been steadily squeezed by logging, plantations, and transmigration, and the environment has also been degraded due to the increasing severity of El Niño events, the effects of fire, rats 
and other pests, reduced biodiversity, and the conversion of vast areas to externally controlled plantations. Although long fallows continue (the people know how their system works and the relevant thresholds to which they must adhere), excessive shortening of fallows does seem possible if in-migration continues and outsiders keep altering the landscape on such a massive scale. Climate change is likely to reduce the viability of their system further.

From a cultural point of view, the increasing contact with ethnic groups who demean the Uma' Jalan as "primitive" and "backward" - partly because they cultivate swiddens and despite the appropriateness of the system to the local environment-has a tendency to reduce their selfconfidence and pride in their own way of life. The involvement of the youth in formal education, with some valuable benefits, has the perverse effect of speeding the loss of traditional ecological knowledge.

Some changes are ambiguous. Women's traditional high status has been compromised by the increasing efficiency of men's agricultural labour (the chainsaw replaced the axe; the outboard motor, which women have trouble lifting, replaced the paddle, making women more dependent on men for travel) and by contact with other, less egalitarian but more powerful ethnic groups. Access to trade is much easier, which increases the people's reliance on money, which in turn has adversely affected their traditional values of generosity, sharing, and mutual dependence. On the other hand, men's ability to find consumer goods closer to home is a strong plus, and money from commerce contributes to access to education, medicine, and other desired goods. Finally, links between the community and government have strengthened. On the down side, this has reduced people's autonomy and freedom. On the up side, it means they have access to sources of government revenue, expertise and programs.

Case 3: Rubber Transforming Swidden Landscapes, Property, and Identities in West Kalimantan, Indonesia

In the West Kalimantan village of Bagak Sahwa, rights and claims to land and trees have changed significantly and in many different ways over the past 40 years since land use has changed from a predominance of swidden cultivation to a predominance of relatively permanent tree crop production. Rubber is one of the main tree crops that has replaced swidden production in this landscape, and provides a lens through which to explore the property and identity transformations that accompany the transformation of the swidden landscape. Swidden agroforestry in Bagak Sahwa always involved the management of trees in the broad swidden landscape: fruits cultivated in fallows or near longhouses for food; other self-sown and cultivated forest and garden or tree crops for cash. While rights to swidden fields under cultivation were held by the descendants of the original forest-clearer, fruit and forest-product rights generally inhered in the trees. In other words, rights in trees and land could be held separately. Through various mechanisms, the longhouse or village community recognized a broader territory over which it had authority, reinforced by colonial institutions of indirect rule.

After the formation of the Republic of Indonesia, the village customary rights were not officially recognized, and land rights remained fuzzy even after the passing of the Basic Agrarian Law in 1960. As a result, property rights and access to land and economic trees changed over time in ways that were somewhat haphazard, or at least not planned either by government or local people. Two major processes, sedentarization and commoditization, which at times articulated with government policies, had the effect of changing rights to swidden fallows and ancestral fruit trees from being held by descent groups to an emphasis on individual rights to parcels of land (Peluso 2005). Both these processes were facilitated by increasing access to markets through road improvements, increasing urbanization, and increased demand for fruit and rubber. The rates and types of change in rights depended in part on the types of trees and how these were planted. Rubber is planted in clusters to facilitate latex collection and thus creates small territories of rubber lands even within individual swidden fallows containing other sorts of trees.

Salako Dayaks in Bagak Sahwa started growing rubber around the 1930s. Today rights to rubber land are privately held (by households), but different processes have led to different types of private rights in different parts of the landscape. Rubber is also considered a Dayak crop, or sometimes a crop grown by other pribumi - the term used to indicate Indonesian citizens of non-Chinese origin. Dayaks grow rubber on plots that were once swidden fallows, in PPKR (Proyek Perkebunan Karet Rakyat or the People's Rubber Garden Project) smallholder schemes, and, along with migrants from other parts of Indonesia, in transmigration areas. Each of these types of land has produced different types of racialized territories, glossed with ethnic or nationalist identities. ${ }^{2}$

Swidden fallows have the longest and most "traditional" history of Dayak claims. In its early years in Bagak Sahwa, and where land allocations still permit, rubber could be part of a long-term swidden cycle. After rice and vegetables were harvested, and maybe a crop or two of corn, groundnuts or banana, rubber could be planted in fallows, taken care of for 7 years or so before producing latex, and

\footnotetext{
${ }^{2}$ Colfer (pers. comm.) notes a similar ethnic identification with particular crops in West Sumatra; in this case, rubber is associated with Minangkabau. Potter (1987) also describes the association of different land uses with ethnic identities in South Kalimantan.
} 
then tapped as the owner saw fit for 20-30 years. Over time, with sedentarization, rubber had significant transformative effects on the property rights in swidden landscapes. Rights to swidden fields under cultivation were held by the cultivating household but the larger descent group had access to the fallows. As more farmers planted rubber and other trees in their fallows, the landscape filled up with trees. Rice harvests were no longer enough to feed a family for a year. Fallow periods on lands without rubber were necessarily reduced because less land for field cropping was available. This meant that farming-dependent families had to produce enough rubber to sell and buy rice and other daily needs. The long tenure of rubber (and other trees) in the landscape resulted in a de facto change in the dominant property rights regimes, effectively privatizing what had been a communal descent-group system with only temporary private rights.

The second location where Dayaks grew rubber was in government-sponsored smallholder rubber schemes (PPKR). This project introduced clonal varieties of rubber for smallholder pribumi, including Dayaks. Households participating in PPKR were granted loans for inputs and seedlings of cloned rubber trees. Another condition of participation was that the village identified a block of contiguous land to facilitate the clearance of the area with herbicides, applications of other inputs, and monitoring by project officers who visited occasionally. At the end of the loan period, households received a private title to the land. Though it was not stated as such, PPKR had the effect of transforming land from its "fuzzy" status as "customary land" under the authority of the village or descent groups to privately held titled lands, authorized by the state. PPKR thus also empowered the state, bringing it into the everyday lives of local people in a new way. Enough land (over 200 ha) was converted to PPKR rubber so that any family willing to take the loan could get a hectare or more.

The third site where Dayaks grow rubber, also clonal varieties, are transmigration sites. The one near Bagak Sahwa was constructed in the mid-late 1980s, technically within the territory of an adjacent Salako village, which had been an expansion site to which some Bagak Sahwa villagers moved in the early 1930s (Peluso 1996). This 800-ha transmigration project was meant to bring in 400 families from Java, Sunda, Bali, and Irian. The project also integrated Salako villagers, transforming their swidden land as part of the 800 ha reallocated to households. Besides its transformation of the land cover and the property rights on that land, the transmigration site was also highly symbolic of a national identity, literally inserting the nation-state into the local territory. Its mix of local and national pribumi also represented national "unity in diversity" (the official Indonesian motto). Transmigration participants were granted private titles to their land at the end of the loan period.
Rubber production on swidden fallows and other types of communal lands not only produced new private rights and kinds of territories - it also produced identities. At a national and regional level, rubber came to be associated with indigenous Dayak and other pribumi smallholders. Rubber also helped construct their own collective identities as being modern, Indonesian citizens, and commodity producers. But Dayak and pribumi identity came at a price: the elimination of certain people from the landscape and population history.

Bagak Sahwa is located in a part of West Kalimantan that the Dutch referred to as "the Chinese Districts". In 1918 the subdistrict in which Bagak Sahwa was located housed an estimated 20,000 Chinese, 14,000 Malays and 5,000 Dayaks. Hakka-speaking miner-farmers had flocked to western Borneo in the late eighteenth and early nineteenth centuries to mine for gold. Some specialized in farming. They converted swamp and swamp forest to agriculture, creating the thousands of hectares of wet rice fields (sawah) all along the coastal rivers. For the first 100 years or so, virtually all Chinese migrants were men. If they stayed, they married or partnered with local women, again almost always Dayak women. Mixed marriages continued even after the end of the nineteenth century when women began to migrate from China as well. Being mixed Chinese-Dayak (termed "Bendi" or "local") was not an issue in this locality. It was only after the Dutch asserted control that it was considered an anomaly. Dutch governed what they saw as native and alien populations by different rules and it was necessary to differentiate between "native Dayaks" and "alien Chinese".

Rubber and rice production practices were both indicators and producers of racialized identities during both the colonial and contemporary periods. Sawah rice in this part of West Kalimantan was invariably defined as Chinese, swidden was Dayak. Rubber-growing techniques were also differentiated. One observer described rubber growing by Chinese as: "Neat roadside gardens, mono-cropped plots, highly efficient, land inherited by sons, farms using family and coolie labor". By 1930 not only were certain types of rubber growing associated with Chinese but rural Chinese were invariably assumed to be smallholder rubber producers. Dayak rubber, on the other hand, was seen as having been integrated into their swidden landscapes, producing different kinds of landscape effects. Officials who remarked on their production emphasized the disorder and "messiness" of these farms. What Bendi did in either landscape, or the fact that "Chinese landscapes" were in fact the product of Bendi labours, was never mentioned.

In the colonial period, identity became linked to the capacity to own land legally. Chinese, as "foreign Orientals", could not own land during this period of racialized indirect rule. Nevertheless, Chinese and Bendi land was 
recognized by local Dayaks and their leaders. They used land that Dayaks in fact had not wanted to use, draining the swamps and creating sawah, using some lowland tracts for tree crops, while Dayaks, including those of Bagak Sahwa, preferred the hills. Bendi-Chinese improved and irrigated the land and passed it on to their descendents. The official regulations were largely irrelevant to many everyday practices.

These problems of recognition and land rights were not resolved with Indonesian independence. The racial differences and landscape practice associations were also carried over into the independent period. Swidden and fallow agroforestry, subsistence production, or selling rubber and tree crops for subsistence rendered people "Dayak". The simple, native, local identity is reproduced in racist ways today through the recently coined term, "jungle rubber". Because rubber took off so well among Dayaks in the interior and has been written about as a smallholder swidden cash crop so widely, its early, long-term associations with Chinese were forgotten.

Violence against "Chinese" finally eliminated them from rural West Kalimantan, with a few exceptions. After 1965 the political economic terrain had changed. The former Chinese districts were considered a security threat, both because being "Chinese" was conflated with being communist and because it was assumed that local Chinese (many of whom were in fact Bendi) would protect other Chinese who were communist. But ethnicity was still murky in this area. Hence the Indonesian militarycomprising mostly soldiers from Java, Sumatra, and elsewhere - spent months mobilizing "Dayaks" so they would turn against "the Chinese". Eventually, in 1967, a "Demonstration" was orchestrated, and it spread throughout the Chinese districts from the coast to the interior. Chinese were evicted to cities and camps; some were resettled in special locations. Their land and houses were expropriated: sawah rice-fields, rubber gardens, home gardens. Through various processes, local and involving government, these extensive lands were reallocated to pribumi remaining in rural areas, which were now areas of indigenous authenticity and symbols of the Indonesian nation.

A new frontier of sorts had been created, however, by the land abandoned by Chinese that was not immediately occupied. There was so much empty land in Bagak Sahwa and neighbouring villages that despite its being reallocated to any pribumi who wanted it, whether local or a recent migrant, there was a great deal still unclaimed and lying fallow. In 1989 some 800 ha became a transmigration site; some 209 ha became a PPKR smallholder scheme. There were also some rubber plots inside the village territory that had once been owned by Chinese and Bendi, taken over by local Dayaks and Madurese. In some cases these were kept as rubber gardens and tapped by the new owners. In others they were remade as "Dayak" first: the trees cut, the land swiddened, and new rubber and fruit gardens planted (though many swidden fallows where rubber was planted were old Dayak holdings). Thus all three kinds of land on which smallholder rubber is today produced by Dayaks have associations with Chinese or Bendi, some dating back 200 or 250 years.

This case study shows that both policy and local practices related to the transformation of the swidden landscapes in this region have contributed to the hardening of ethnic identities, in large part because ethnicity was used by colonial and contemporary governments as a means of delineating rights and access to land and land-based resources. Further, in this part of West Kalimantan, violence has further hardened and racialized identities and had the effect of racializing territories in the landscape.

\section{Case 4: Swidden Agriculture as a Communal Safety Net in Jambi, Indonesia}

This case study from Rantau Pandan Sub-District in Jambi Province on the east coast of the island of Sumatra shows how swidden cultivation provides a safety net that smallholders can fall back on during crisis situations. This function is provided through customary land that is reserved for swidden cultivation. With the bulk of land converted to rubber agroforestry, local communities still maintain the use of communal land as a buffer that can be accessed during a shock to their livelihood system, such as a decline in the price of rubber.

Swidden cultivators in Rantau Pandan practise a form of rotational agriculture, with a fallow period longer than the period of cultivation. Land is used for only 1 to 3 years and fallowed for a relatively long period, depending on land availability. The system is based on cutting and burning fallow vegetation in the dry season. Farmers plant upland rice and secondary crops such as yellow bean (Phaseolus vulgaris). After harvesting the rice, beans, and other crops, they sometimes plant additional crops such as chillies on part of the land. In the following year, upland rice may be planted again, but declining soil productivity and increasing weed problems lead farmers to rest fields after 2 to 3 years. Other types of vegetation then take over and the field eventually grows into secondary forest (or forest-fallow) before the cycle is repeated. The length of fallow varies considerably, from 5 to 20 years, but sometimes may not even attain 5 years. In many cases rubber seedlings are planted along with the rice with a view to converting the field to a rubber garden. If the rubber seedlings fail to survive, the usual forest-fallow is allowed to take over. If the rubber grows well, it is managed until the rubber is mature and can be tapped. This kind of rubber holding has been termed a "managed swidden fallow" (Cramb 1993). 
The recent history of swidden transformation in this area can be viewed in three phases. First, in the 1970s and 1980s, when the rubber price was high and steady, farmers were more interested to plant rubber in their swidden lands. They regarded this system as well-suited to the local environment and it was sustained by the favourable market conditions. Rubber enabled farmers to increase farm income as well as meet their subsistence needs without greatly disturbing the local farming system, at least in the beginning. Second, from the 1990s until early 2002, when the price of rubber fluctuated around a decreasing trend, farmers lost interest in rubber and preferred to practise swidden cultivation. However, from 2002, due to the high and increasing price of rubber, they have started planting and tapping rubber again. Only a few swidden cultivators could be found during a field visit in 2008, and most of them were landless households (using communal land). This confirmed survey results, showing a decline in the proportion of households engaged in swidden from $90 \%$ in 2000 to $8 \%$ in 2005 , and a decline of $76 \%$ in the area of upland rice over the same period, despite an almost constant population density (Table 1).

However, along with the expansion of rubber, local communities in Rantau Pandan have still maintained the option of swidden cultivation on customary or communal forest land that is designated for this purpose. About 800 ha of communal forest land have been "preserved" for upland rice cultivation within the sub-district. These areas are about 1-2 $\mathrm{h}$ walking distance from the village centre and include hilly land that villagers believe to be relatively fertile. It is not clear whether this area of communal forest land overlaps with state-owned forest land under forest plantation concessions (HTI) or the conservation forest of the Kerinci Seblat National Park. Nevertheless, the village leader controls the use of this communal area on behalf of the community. Customary tenure is strongly enforced in order to maintain the existing swidden system for production of upland rice as part of a local food security strategy. No tree crops are

Table 1 Population and agricultural land use in Rantau Pandan SubDistrict, 2000 and 2005

\begin{tabular}{lcc}
\hline Year & 2000 & 2005 \\
\hline Population density (persons/sq.km) & 13.44 & 13.11 \\
Average household size & 4.12 & 3.73 \\
Lowland rice area (ha) & 2,123 & 785 \\
Upland rice area (ha) & 1,033 & 248 \\
Lowland rice yield (t/ha) & 4.07 & 4.21 \\
Upland rice yield (t/ha) & 1.42 & 2.09 \\
Maize area (ha) & 130 & 37 \\
$\%$ of households cultivating swiddens & 90 & 8 \\
\hline
\end{tabular}

Source: Biro Pusat Statistik (2002, 2005); ICRAF survey data allowed in these swidden reserves. Members of the community are free to use the land, but landless households (those without inherited land) get priority. Outsiders have to get permission from the customary leader to use it. Generally, a household is able to cultivate about 1-2 ha of upland rice before allowing the land to revert to fallow. Given the recent rubber boom, much of this land is presently left fallow and covered by small trees and shrubs (sesap).

Table 2 shows the distribution of surveyed plots by land use and tenure in Rantau Pandan in 1999. Communal or lineage ownership was the dominant form of tenure for upland rice plots. A process of individualisation of land tenure has been underway, especially for rubber plots, with collective ownership by kin groups evolving to individual family ownership, and a matrilineal inheritance system (whereby only daughters inherit land) evolving into a bilateral system (with daughters and sons inheriting). Hence a 2008 survey found that upland rice cultivation now occurs more frequently on joint and single family land rather than communal land. ${ }^{3}$ This is because farmers want to interplant rubber with the rice and so need to use their private land. However, the fact that farmers still maintain their communal land for swidden cultivation shows that in the future they can revert to this activity. Though farmers in 2008 could easily obtain their rice supplies by selling rubber, they were not intending to convert all their plots to permanent crops. The communal swidden reserve was being maintained, though at the time of the survey in 2008 much of it was under secondary growth, in some cases up to 20 years old.

In some areas it appears that communal ownership of forest land for swidden cultivation is not always strongly enforced. Community members can plant swidden lands with rubber and can freely buy and sell land, as has happened increasingly in the past decade. Strong local-level institutions to enforce the function of this communal land are the key to maintaining swidden as a buffer in the face of economic and other shocks to the livelihoods system. Research by Arifin and Hudoyo (1998) in the study area shows that upland rice cultivation with a long fallow period (10 years or more) gives a better return per hectare cultivated than traditional wet rice (IDR 39,427 compared with IDR 19,054), due to higher labour and fertiliser costs and only marginally higher yields in wet rice cultivation. Further research in 2006 from the same study area shows that the traditional upland rice system gives a return to labour of IDR 5,920 per day, compared to IDR 3,680 per day for wet rice using local rice varieties. ${ }^{4}$ Thus, it is clear that swidden is still capable of providing an important

\footnotetext{
$\overline{3}$ Joint family tenure here and in Table 2 refers to ownership by several closely related families rather than the entire lineage.

${ }^{4}$ The exchange rate on 24 September 2008 was USD 1=IDR 9,332.
} 
Table 2 Distribution of sample plots in Rantau Pandan by land use and tenure, 1999

Source: Suyanto (1999)

\begin{tabular}{lcccc}
\hline Tenure type & Upland rice & Young rubber & Mature rubber & Forest-fallow \\
\hline Communal/lineage & 67 & 0 & 0 & 0 \\
Joint family & 4 & 0 & 0 & 0 \\
Single family & 11 & 35 & 24 & 37 \\
Private-purchased & 0 & 44 & 53 & 21 \\
Private-forest clearance & 4 & 15 & 10 & 37 \\
Renting & 0 & 0 & 9 & 0 \\
Borrowing & 11 & 6 & 5 & 0 \\
Others & 4 & 0 & 0 & 0 \\
\hline
\end{tabular}

subsistence safety net. With the recent increase in rice prices the value of these communal swidden reserves may well be coming in to play again.

Case 5: State-Sponsored Migration, Intensification, and Return to Swidden in the Central Highlands of Vietnam

The Central Highlands of Vietnam (Tây Nguyên) are a region of mountains and plateaus spread over five provinces-Kon Tum, Gia Lai, Dak Lak, Dak Nong, and Lam Dong. At the time of reunification in 1975, this region was the dwelling place of 20 ethnic groups who had been residing there for possibly thousands of years. Their livelihood strategies were based on swidden cultivation in combination with livestock raising and small-scale collection of forest products (timber and non-timber), primarily for subsistence. These livelihood activities were not merely a way of earning a living but were pursued in accordance with their own cosmology, knowledge, beliefs, and subsistence ethic, generated from a long period of adaptation to the natural environment and their relative isolation from higher-level political structures.

Following the Marxist theory of "universal linear progressive growth", socialist government planners viewed the ethnic groups of the Central Highlands as primitive societies. The most important feature identifying these people to be at the lowest stage of development was their swidden cultivation. For instance, Nguyen Tan Dac reflects the central government's view when he writes: "The ethnic people in the Central Highlands have known how to use forestland for shifting cultivation, which means they know how to adapt to their natural environment; however shifting cultivation has kept these people standing at the startingpoint of the evolutionary ladder, or the lowest stage of civilization" (Nguyen Tan Dac 2005: 80).

Guided by such perceptions, numerous development programs have been implemented to help the Central Highlanders attain a "higher development stage" or, to use Khieu's terms, "to bring progression, prosperity and happiness for all Highlanders" (Vu Khieu 1986: 26).
During the period of central planning, these development programs included:

- "Fixed Cultivation and Fixed Settlement" (Định Canh Định $\mathrm{Cu}$ ) to help ethnic minorities achieve "stable lives";

- "Collectivization" (Hợp Tác Hoá) to replace rotational shifting cultivation or "irrational" agricultural production;

- "Constructing a New Way of Life and Culture" (Xây Dụing Đời Sống Mới và Văn Hoá Mới) to help the "primitive people" learn more about "scientific knowledge" and to transform themselves into "New Socialist Men" (Con Nguời Mới Xã Hội Chủ Nghĩa);

- "Constructing New Economic Zones" (Xây dụng vùng Kinh Tế Mới) aimed at bringing lowlanders or skilled workers to the region to help ethnic minorities obtain a "higher developmental stage" quickly;

- “Constructing Large-Scale Production” (Xây Dụing Nền Sản Xuất Lớn Xã Hội Chủ Nghĩa) to make "effective utilization" of the land and forest resources to meet the needs of the national society and the ethnic minorities (Le Duan 1976: 265).

Since the government started its "renovation process" in the 1980s, these development programs have been changed into programs for "industrial plantations", "cash crops" and, more recently, "poverty alleviation".

Most of the ethnic minorities in the Central Highlands, instead of being "developed" after 30 years of these statesponsored development programs, are finding themselves under increasing pressure due to land scarcity and conflicts over forest resources. For these ethnic groups, as described by Salemink (2003), the development programs implemented by the socialist state have meant their cultivable land was taken over by cooperatives in which the newly arrived Kinh settlers participated, and their forests became the property of state forest enterprises. At the same time, the remaining land and forests of the minority groups have become contested sites, seriously threatening their survival. As a result, many families are now landless and without resources. In 2004 an official report recorded that more than 
$50 \%$ of ethnic minority households in the Central Highlands - that is, around 86,000 households or half a million people-were living under the national poverty line with poor living conditions and lack of cultivable land. ${ }^{5}$ More important, land and forest scarcity have led to erosion of local culture and the emergence of numerous internal contradictions and social conflicts within the minority groups themselves.

A study of Plei H'Let, a small Bahnar (Mon-Khmer) village situated in the northeastern part of the Central Highlands, illustrates how the destruction of customary cultural practices has led to numerous conflicts causing irretrievable community disruption and even loss of life (Le Quang Trung 2007). ${ }^{6}$ First, these villagers were settled within a planned area. They also joined in an early agricultural co-operative with Kinh people who had migrated to the area under the Program for Constructing New Economic Zones, practising "more advanced cultivation" (wet-rice cultivation). However, in contrast to the bright promises described in the manuals of these development programs, the villagers suffered food shortages. Moreover, most of their cultivable land was lost to Kinh farmers after the collapse of the agricultural co-operative. Most of the families in the village had to return to the swidden areas they had cultivated during the war in order to survive.

When the progam on "cash crops" came to Plei H'Let, the villagers tried to develop coffee plantations. In an attempt to develop this "high benefit plantation", some families sold a part of their cultivable land in order to have money for investment, while others borrowed money or made agreements with Kinh settlers for joint investment in coffee plantations. What were the effects of entering into these commercial arrangements? Most of the Bahnar families who had planted coffee said that their decision was a serious mistake. The coffee plantations required a large investment; the more trees they grew, the larger the investment required. However, the world price of coffee fell dramatically in 2000-2001, partly due to the rapid expansion of production in the Central Highlands. Villagers reported that when they started to plant coffee, the price of fresh beans was $6,000 \mathrm{VND} / \mathrm{kg}$, but 5 years later it had fallen to $800 \mathrm{VND} / \mathrm{kg}^{7}$ Hence, the more people had invested in their plantations, the greater their financial loss. About half the families who had planted coffee had to replace their coffee trees with traditional crops in order to stop losing money.

\footnotetext{
$\overline{5}$ According to the government's current poverty classification, families with income per capita less than US \$6/month are recorded as poor households.

${ }^{6}$ The name of the village has been changed.

${ }^{7}$ In August 2008 the exchange rate was 1 USD=16,545 VND.
}

For one of the poorest families in the village, coffee planting became a tragedy. The family had made an agreement for a joint investment in a coffee plantation with a Kinh family. They contributed 1.2 ha of their land for the coffee plantation while the Kinh family contributed 1,000 coffee seedlings and some chemical fertilizers. One year after planting, the Kinh family asked to have the planted area divided into two portions, with $60 \%$ belonging to the Kinh family and the remaining $40 \%$ belonging to the Bahnar family. The latter did not agree with this division, insisting on $50 \%$ of the coffee plantation, but the Kinh family did not accept this. To claim his land, the head of the Bahnar family cut down some coffee trees in the area that the Kinh family wanted to take over. This resulted in the head of the Bahnar family being beaten up, following which the Kinh partner sold the entire coffee plantation to another Kinh family without giving any money to the landowners. This incident reflects the lack of legal or other forms of recourse available to poor Bahnar families in this context. After this failed attempt to change their livelihood by planting coffee, the Bahnar family had to move further into the forest in order to survive through small-scale swidden farming and collection of minor forest products.

As a result of such processes, in the last few years the Central Highlands have become a hotspot of ethnic movements, social conflict, and contestation related to questions of land and forest resources. There were two large ethnic demonstrations in the Central Highlands in late January 2001 and early April 2004 on the streets of Ban Me Thuot, Pleiku, and other centres. Participating in the demonstrations were thousands of ethnic minorities. Their purpose was to claim ancestral land and forests and to resist state development programs (Salemink 2003: 287). In some places, ethnic minorities have supported illegal loggers (lâm tặc) or become "illegal loggers" themselves, as a form of protest (Nguyen Ngoc 2002; Salemink 2003). Recently, 10,000 minority households have moved to very remote areas, practising swidden cultivation and maintaining their customary practices, in order to deal with their immediate problems (Khong Dien 2002; Dang Nghiem Van 2002).

All these social phenomena are raising questions regarding the situation of ethnic minorities in the Central Highlands under the government's development policies. More generally, this case study indicates that the transformation of swidden landscapes into more intensive production systems through state-sponsored in-migration and development programs can simultaneously create wealth and poverty, and that reversion to swidden may be the only alternative for those on the losing end of these processes. 
Case 6: Multiple Responses to the Regulation of Swidden in Northern Thailand

In Thailand's northern uplands, territorial control and the state's attempt to regulate swidden agriculture have been politically contentious. ${ }^{8}$ Between 1960 and 1990, reforestation projects and rapid expansion of protected areas have led to enclosure of the lands of hundreds of tribal communities. Local responses have been varied, combining political movements, supported by NGOs and academics, with community and household adaptations. Counter movements by NGOs and local people against the state's pejorative perception of swidden agriculture have been carried out through the campaign towards legal recognition of land rights over swidden and fallow, and raising public awareness regarding the role of swidden in biodiversity conservation. These campaigns have been augmented by the invention of a new discourse of swidden as "rai mun wian"- a rotational form of agriculture - in contrast to the state's derogatory term of "rai luan loy"-_drifting agriculture", implying a chaotic, irresponsible, and destructive form of upland farming.

In 2001, a 99-day demonstration in front of the parliament building by members of the Northern Farmers' Network resulted in a Cabinet Resolution to approve research into swidden agriculture in northern Thailand, to be undertaken by Chiang Mai University's Faculty of Social Sciences in collaboration with Kasetsart University's Faculty of Forestry, the Northern Development Foundation, the Indigenous Mountain People for Education and Culture Association, and the Northern Farmers' Network. The 15month research effort in Mae Hong Son, Lampang, Chiang Mai and Chiang Rai provinces has demonstrated complex forms of swidden transformation due to different degrees of state sanctions and the availability of distinct alternatives. In the 11 villages of the research areas (ten Karen and one Lahu), it was found that state enclosures have resulted in the alteration of upland swidden communities in three directions: (i) transformation with reliance on swidden agriculture; (ii) transformation with reliance on forest resources; and (iii) transformation with dependence on cash crops. Table 3 provides some background information on these villages, grouped according to the direction of change.

The first group of swidden communities has experienced a moderate impact from the state's conservation policy and has been able to maintain an adequate rotational process with cycles of between 5 and 7 years. Local institutions of resource tenure remain strong and customary laws are still practised. Cash-crop production plays a minor role and is a

${ }^{8}$ For background to this case see Grandstaff (1980), Schmidt-Vogt (1998) and Laungaramsri (2005).

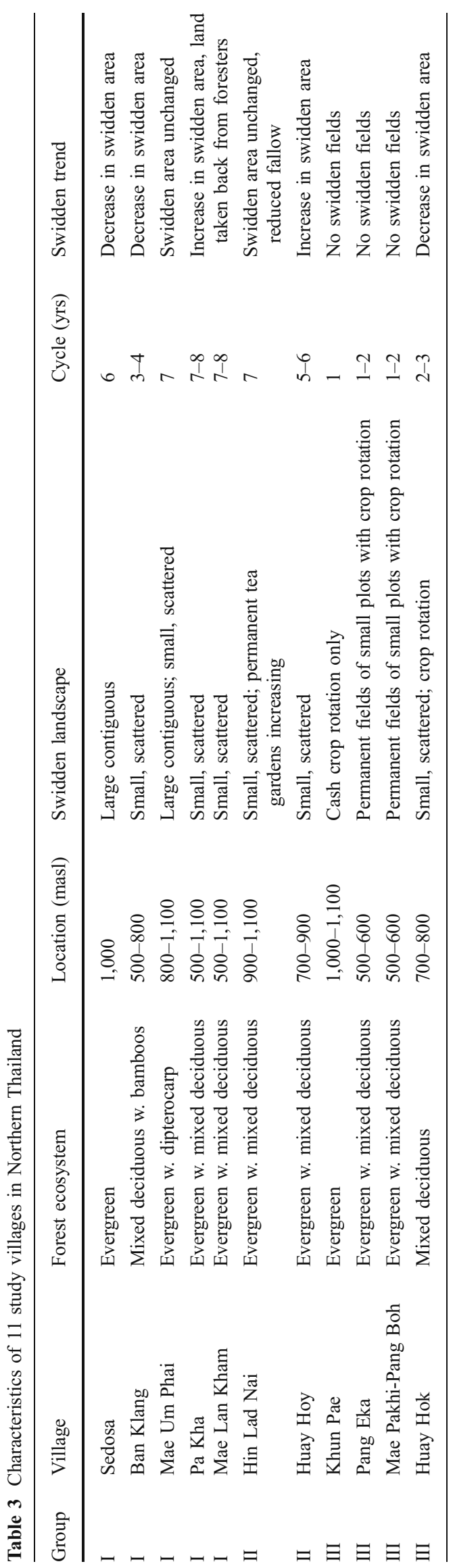


supplementary source of income due to the difficult access to markets and limited capital.

The second group has been forced to reduce the area of fallow land. Rice production within this group has not declined significantly but villagers have decided to diversify their livelihood choices by enhancing their available natural resources. Although land disputes have increased due to insecurity of land rights, traditional institutions are still intact and able to ensure sustainable use of resources and livelihood security.

The last group comprises communities that have suffered severe loss of land to the Royal Forestry Department's reforestation projects and have been forced to completely abandon swidden cultivation. As a result, villagers have to rely entirely on the market economy for their living. Intensive cash cropping with widespread use of chemicals and wage labour has replaced subsistence rice production. At the same time, individualisation of land tenure has become common as traditional local institutions managing communal land have been weakened.

The ability to cope effectively with land loss has depended significantly on external support. Khun Pae Village in Chiang Mai Province has been substantially subsidised by the Royal Project (the King's special fund established in 1969 for "hill tribe" research and development) and allowed a 14-year period of transformation into wet rice and cash crop cultivation. In contrast, deprivation of land with no assistance in Pang Eka, Mae Pa Khi, and Huay Hok villages in Chiang Mai and Chiang Rai provinces respectively has driven local villagers into insecure livelihoods and acute rice shortages.

Various coping strategies have been developed among the three groups of villages. Their aims are threefold: to maintain rice productivity, increase the level of household income, and ensure the security of land tenure. The ability to achieve these aims among the three groups depends on the degree of state enclosure and the availability of forest resources.

In maintaining rice productivity, villagers employ two major strategies: the expansion of paddy fields and the intensification of land use. The expansion of paddy fields is considered by villagers as the most effective and desirable strategy but it is not feasible in those villages located at high elevations. Intensifying land use is pursued in four ways: (i) shortening the period of fallow as long as sufficient land for a sustainable rotation cycle is still available; (ii) consolidating swidden fields of several families and pooling labour when fallows have become short and weeds a major problem, and pooling the grain in a collective rice storehouse; (iii) dividing up the remaining land into small plots with a constricted rotation; and (iv) turning small swidden fields into permanent land use with cash crops and crop rotation. The third and fourth methods are employed mostly by the third group of villages and involve heavy use of chemicals due to proliferation of weeds and rapid soil deterioration.

In order to earn cash income, households in the 11 villages have sought off-farm income and cash cropping as their alternatives. However, both the options available and those chosen vary. Where land reduction is not so severe, as in the first group of villages, households tend to combine the selling of non-timber forest products and traditional agroforestry to increase the level of income. In the second group of villages, which is mostly located in the mixed deciduous forest, a number of alternatives have been incorporated, including selling non-timber forest products and cattle, eco-tourism, tea farming, and cash cropping. This combination of various sources of income helps reduce the risk caused by fluctuating crop prices. In the third group, households rely heavily on cash cropping and wage labour as the major source of income. Compared to the other two groups, the level of cash income of the third group is generally higher. However, the level of debt is also higher. As villagers have no control over the market price and employment is often temporary, most income is used to pay off debts. With limited alternatives and a high dependence on the market, the livelihood of this group of villages is more at risk than that of the others.

Local responses to the insecurity of land tenure have also been varied, depending on the strengths and weaknesses of local institutions. In the first and second groups of villages where local institutions remain strong, villages have attempted to create mechanisms to prevent further land loss, such as issuing regulations to prohibit the sale of land to outsiders. Some villages have also agreed to rearrange and reclassify their land use, giving up certain swidden areas so that these can revert to forest and become part of their community forest. In contrast, in the third group of villages, where local institutions are relatively weak, there is a tendency towards the individualization of land rights, and conflicts over resource access between rich and poor households have been escalating.

\section{Conclusion}

Swidden cultivators in Southeast Asia have developed complex, sophisticated agricultural systems that have long been an important and viable source of livelihood, providing rice, other food crops, and fallow foods and products. Swidden agriculture has also been central to the social relations and cultural identity of many groups in upland areas. Nevertheless, swidden farmers are proactively responding to the political and economic "drivers of change" in the region. Their responses are themselves an important "driver" of further change. At the household level these responses have included both the intensification and 
"dis-intensification" of swidden land-use, the insertion of cash crops, the redeployment of household labour, and the taking on of broader (often non-rural) livelihood aspirations and strategies. At the community level there have been emerging institutional arrangements for management of land and forests, and varying degrees of participation in or resistance to government schemes and programs. Swidden change has led to the loss and also the reassertion, realignment, and redefinition of cultures and identities, with important implications for access to resources.

The impacts have been varied. Cash crops have often helped improve household livelihoods but complete specialisation for the market increases vulnerability. Thus swidden can still provide an important buffer or social safety net in the face of market fluctuations. Improved access to markets and social provision of education and health care have mostly improved the welfare of previously isolated groups. However, growing differences within and between communities in the course of swidden transformations can leave some groups marginalized and worse off. These processes of differentiation can be accentuated by heavy-handed state interventions based on swidden stereotypes. Nevertheless, communities have not passively accepted these pressures and have mobilized to protect their livelihood assets and strategies.

Thus swidden farmers are not resisting appropriate and supportive forms of development. They are adopting new practices and engaging with markets, but in many situations swidden is still important to their livelihood strategies, providing resilience in the face of turbulent change. Swidden communities have demonstrated that they can manage access to and use of their lands, given appropriate legislative support (e.g., recognition of customary tenure and territorial boundaries). On the other hand, externally imposed, large-scale change (such as restrictive land-use zoning, resettlement, and commercial estates) can affect swidden farmers adversely. Active involvement of local people is essential in planning, implementing, monitoring and evaluating development and conservation programs in swidden lands. Positive market incentives and supportive government policies are better than standardised, top-down directives.

\section{References}

Arifin, B., and Hudoyo, A. (1998). An Economic Analysis of Shifting Cultivation and Bush-Fallow in Lowland Sumatra. Southeast Asia Policy Research Working Paper No. 1. ICRAF, Bogor.

Barlow, C. (1997). Growth, Structural Change and Plantation Tree Crops: The Case of Rubber. World Development 25: 1589-1607. doi:10.1016/S0305-750X(97)00059-4.

Barlow, C., and Jayasurija, S. K. (1986). Stages of Development in Smallholder Tree Crop Agriculture. Development and Change 17: 635-658. doi:10.1111/j.1467-7660.1986.tb00257.x.
Biro Pusat Statistik (2002). Bungo Dalam Angka. Bappeda and Biro Pusat Statistik, Muara Bungo.

Biro Pusat Statistik (2005). Bungo Dalam Angka. Bappeda and Biro Pusat Statistik, Muara Bungo.

Boserup, E. (1965). The Conditions of Agricultural Growth: The Economics of Agrarian Change under Population Pressure. Earthscan, London.

Brookfield, H. C. (1972). Intensification and Disintensification in Pacific Agriculture: A Theoretical Approach. Pacific Viewpoint 13: 30-48.

Bruun, T. B., de Neergaard, A., Lawrence, D., Ziegler, A. (2009). Environmental Consequences of the Demise in Swidden Agriculture in Southeast Asia: Carbon Storage and Soil Quality. Human Ecology this issue

Chin, S. C. (1985). Agriculture and Resource Utilization in a Lowland Rainforest Kenyah Community. Sarawak Museum Journal Special Monograph No. 4. Sarawak Museum, Kuching.

Christensen, H. (2002). Ethnobotany of the Iban and the Kelabit. Sarawak Forest Department; NEPCon Denmark; University of Aarhus, Denmark.

Colfer, C. J. P. (2008). The Longhouse of the Tarsier, Changing Landscapes, Gender, and Wellbeing in Borneo. Borneo Research Council, Phillips, ME.

Colfer, C. J. P., and Dudley, R. G. (1993). Shifting Cultivators of Indonesia: Managers or Marauders of the Forest? FAO, Rome.

Colfer, C. J. P., and Soedjito, H. (2003). Food, forest, and fields in a Bornean rain forest: Toward appropriate agroforestry development. In Padoch, C., and Peluso, N. (Eds.), Borneo in Transition: People, Forests, Conservation and Development. Oxford University Press, Kuala Lumpur, pp. 215-223.

Colfer, C. J. P., Peluso, N. L., and Chin, S. C. (1997). Beyond Slash and Burn: Building on Indigenous Management of Borneo's Tropical Rain Forests. New York Botanical Gardens, New York.

Colfer, C. J. P., Wadley, R. L., Salim, A., and Dudley, R. G. (2000). Understanding Patterns of Resource Use and Consumption: A Prelude to Co-management. Borneo Research Bulletin 31: 29-88.

Condominas, G. (2009). Anthropological Reflections on Swidden Change in Southeast Asia. Human Ecology. doi:10.1007/s10745009-9248-z.

Conklin, H. C. (1957). Hanunoo Agriculture: A Report on an Integral System of Shifting Cultivation in the Philippines. Food and Agriculture Organization, Rome.

Cramb, R. A. (1985). The Importance of Secondary Crops in Iban Hill Rice Farming. Sarawak Museum Journal 34: 37-45.

Cramb, R. A. (1988). Shifting Cultivation and Resource Degradation in Sarawak: Perceptions and Policies. Review of Indonesian and Malaysian Affairs 22: 115-149.

Cramb, R. A. (1989). The Use and Productivity of Labour in Shifting Cultivation: An East Malaysian Case Study. Agricultural Systems 29: 97-115. doi:10.1016/0308-521X(89)90057-7.

Cramb, R. A. (1993). Shifting Cultivation and Sustainable Agriculture in East Malaysia: A Longitudinal Case Study. Agricultural Systems 42: 209-226. doi:10.1016/0308-521X(93)90055-7.

Cramb, R. A. (1998). Agriculture and Food Supplies in Sarawak during the Japanese Occupation. In Kratoska, P.H. (Ed.), Food Supplies and the Japanese Occupation in South-East Asia. Macmillan, London, pp. 135-166.

Cramb, R. A. (2000). Soil Conservation Technologies for Smallholder Farming Systems in the Philippine Uplands: A Socio-Economic Evaluation. Australian Centre for International Agricultural Research, Canberra.

Cramb, R. A. (2005). Farmers' Strategies for Managing Acid Upland Soils in Southeast Asia: An Evolutionary Perspective. Agriculture, Ecosystems and Environment 106: 69-87. doi:10.1016/j. agee.2004.07.011.

Cramb, R. A. (2007). Land and Longhouse: Agrarian Transformation in the Uplands of Sarawak. NIAS, Copenhagen. 
Cramb, R. A., and Culasero-Arellano, Z. (2003). Landcare and Livelihoods: The Promotion and Adoption of Conservation Farming Systems in the Philippine Uplands. International Journal of Agricultural Sustainability 1: 141-154.

Dang, N. V. (2002). Land Issues in the Central Highlands. In National Center for Social and Human Sciences, Some Ideas Related to Socio-economic Development for Indigenous Villages in the Central Highlands. Social Science, Hanoi, pp. 325-352.

Dove, M. R. (1983). Theories of Swidden Agriculture and the Political Economy of Ignorance. Agroforestry Systems 1: 85-99. doi:10.1007/BF00596351.

Dove, M. R. (1986). The ideology of agricultural development in Indonesia. In MacAndrews, C. (Ed.), Central Government and Local Development in Indonesia. Oxford University Press, Singapore, pp. 221-247.

Dove, M. R. (1988). The ecology of intoxication among the Kantu' of West Kalimantan. In Dove, M. (Ed.), The Real and Imagined Role of Culture in Development: Case Studies from Indonesia. University of Hawaii Press, Honolulu, pp. 139-192.

Dove, M. R. (1993). Smallholder Rubber and Swidden Agriculture in Borneo: A Sustainable Adaptation to the Ecology and Economy of the Tropical Forest. Economic Botany 47: 136-147.

Dressler, W. (2008). Old Thoughts in New Ideas: Tagbanua Resource Use and State Conservation Measures on Palawan Island, the Philippines. Ateneo de Manila University Press, Quezon City.

Dressler, W. (2006). Co-opting Conservation: Migrant Resource Control and Access to National Park Management in the Philippine Uplands. Development and Change 37: 401-426. doi:10.1111/j.0012-155X.2006.00483.x.

Dressler, W., and Turner, S. (2008). The Persistence of Social Differentiation in the Philippine Uplands. Journal of Development Studies 44: 1472-1492. doi:10.1080/00220380802360966.

Ducourtieux, O., Laffort, J. R., and Sacklokham, S. (2005). Land Policy and Farming Practices in Laos. Development and Change 36: 499-526. doi:10.1111/j.0012-155X.2005.00421.x.

Eder, J. F. (1977). Agricultural Intensification and the Returns to Labour in the Philippine Swidden System. Pacific Viewpoint 18: $1-21$.

Eder, J. F. (1999). A Generation Later: Household Strategies and Economic Change in the Rural Philippines. University of Hawaii Press, Honolulu.

Eder, J. F. (2006). Land Use and Economic Change in the PostFrontier Upland Philippines. Land Degradation and Development 17: 149-158. doi:10.1002/ldr.721.

Ellis, F. (2000). Rural Livelihoods and Diversity in Developing Countries. Oxford University Press, Oxford.

Elmer, M., and Shively, G. E. (1998). Irrigation, Employment, and the Environment in Southern Palawan. Journal of Agricultural Economics and Development 26: 112-135.

Fox, J., Fujita, Y., Ngidang, D., Peluso, N. L., Potter, L., Sakuntaladewi, N., Sturgeon, J., Thomas, D. (2009). Policies, Political-Economy, and Swidden in Southeast Asia. Human Ecology. doi:10.1007/ s10745-009-9240-7.

Freeman, J. D. (1970). Report on the Iban. Athlone, London.

Fujita, Y., and Phengsopha, K. (2008). The gap between policy and practice in lao PDR. In Colfer, C. J. P., Dahal, G. R., and Capistrano, D. (Eds.), Lessons from Forest Decentralization: Money, Justice and the Quest for Good Governance in AsiaPacific. Earthscan/CIFOR, London, pp. 117-131.

Garrity, D. P., Kummer, D. M., and Guiang, E. S. (1993). The Philippines. In Sustainable Agriculture and the Environment in the Humid Tropics. National Academy, Washington DC, pp. 549-623.

Geddes, W. R. (1954). The land Dayaks of Sarawak. HMSO, London. Gerrits, R. V. (1994). Sustainable Development of a Village Land-Use System in Upland Sarawak, East Malaysia. Unpublished Ph.D. thesis, University of Queensland, Brisbane.
Grandstaff, T. (1980). Shifting Cultivation in Northern Thailand: Possibilities for Development. The United Nations University, Tokyo.

Grijpstra, B. G. (1978). The Transition from Shifting Cultivation to Cash Crops: Changes in a Land Dayak Village. Studies in Third World Societies 3: 113-138.

Hansen, T. S., and Mertz, O. (2006). Extinction or Adaptation? Three Decades of Change in Shifting Cultivation in Sarawak. Land Degradation and Development 17: 135-148. doi:10.1002/ldr.720.

Hatch, T. (1982). Shifting Cultivation in Sarawak: A Review. Sarawak Department of Agriculture, Kuching.

Jakobsen, J., Rasmussen, K., Leisz, S., Folving, R., and Nguyen, V. Q. (2007). The Effects of Land Tenure Policy on Rural Livelihoods and Food Sufficiency in the Upland Village of Que, North Central Vietnam. Agricultural Systems 94: 309-319. doi:10.1016/j.agsy.2006.09.007.

Jensen, E. (1974). The Iban and Their Religion. Clarendon, Oxford.

Khong, D. (2002). Contribution to Socio-economic Study in the Central Highlands. In National Center for Social and Human Sciences, Some Ideas Related to Socio-economic Development for Indigenous Villages in the Central Highlands. Social Science, Hanoi.

King, V. T. (1986). Land Settlement Schemes and the Alleviation of Rural Poverty in Sarawak, East Malaysia: A Critical Commentary. Southeast Asian Journal of Social Science 14: 71-99. doi: $10.1163 / 080382486$ X00083.

Laungaramsri, P. (2005). Swidden Agriculture in Thailand: Myths, Realities, and Challenges. Indigenous Affairs 2/05: 6-12.

Le, D. (1976). Socialist Revolution in Vietnam. The National Political, Hanoi.

Le, Q. T. (2007). Disrupted Social Transformation of Ethnic Minorities in the Central Highlands, Vietnam. MA thesis, Chiang Mai University, Chiang Mai.

Leaman, D. J., Yusuf, R., Sangat-Roemantryo, H., and Arnason J.T. (1996). The Contribution of the Ethnobotanical Research to Socioeconomic and Conservation Objectives: An Example from the Apo Kayan Kenyah. In Padoch, C., and Peluso, N. (Eds.), Borneo in Transition. Oxford University Press, Singapore.

Lestrelin, G., and Giordano, M. (2007). Upland Development Policy, Livelihood Change and Land Degradation: Interactions from a Laotian Village. Land Degradation and Development 18: 55-76.

Li, T. M. (2002). Local Histories, Global Markets: Cocoa and Class in Upland Sulawesi. Development and Change 33: 415-437. doi:10.1111/1467-7660.00261.

Manivong, V., and Cramb, R. A. (2008). The adoption of smallholder rubber production by shifting cultivators in Northern Laos: A Village Case Study. In Snelder, D. J., and Lasco, R. D. (Eds.), Smallholder Tree Growing for Rural Development and Environmental Services: Lessons from Asia. Springer, New York, pp. $117-138$.

Masyhuri, Cramb, R. A. (1995). A socio-economic assessment of land-use practices in a transmigration settlement on acid soils in south Kalimantan, Indonesia. In Date, R. A., Grundon, N. J., Rayment, G. E., and Probert, M. E. (Eds.), Plant-Soil Interactions at Low $\mathrm{pH}$ : Principles and Management. Kluwer, Dordrecht, pp. 685-688.

Mayer, J. (2003). Impacts of the East Kalimantan fires of 1982-1983 on village life, forest use, and land use. In Padoch, C., and Peluso, N. (Eds.), Borneo in Transition: People, Forests, Conservation and Development. Oxford University Press, Kuala Lumpur, pp. 232-268.

McCarthy, J., and Cramb, R. A. (2009). Policy Narratives, Landholder Engagement, and Oil Palm Expansion on the Malaysian and Indonesian Frontiers, The Geographical Journal, in press.

Mercer, D. E. (2004). Adoption of agroforestry innovations in the tropics: A review. In Nair, P. K. R., Rao, M. R., and Buck, L. E. (Eds.), New Vistas in Agroforestry. Kluwer, Dordrecht, pp. 311-328. 
Mertz, O. (2002). The Relationship between Length of Fallow and Crop Yields in Shifting Cultivation: A Rethinking. Agroforestry Systems 55: 149-159. doi:10.1023/A:1020507631848.

Mertz, O., and Christensen, H. (1997). Land Use and Crop Diversity in Two Iban Communities, Sarawak, Malaysia. Geografisk Tidsskrift-Danish Journal of Geography 97: 98-110.

Mertz, O., Wadley, R. L., Nielsen, U., Bruun, T. B., Colfer, C. J. P., de Neergaard, A., Jepsen, M. R., Martinussen, T., Zhao, Q., Noweg, G. T., and Magid, J. (2008). A Fresh Look at Shifting Cultivation: Fallow Length as an Uncertain Indicator of Productivity. Agricultural Systems 96: 75-84. doi:10.1016/j. agsy.2007.06.002.

Mertz, O., Padoch, C., Fox, J., Cramb, R. A., Leisz, S. J., Nguyen, T. L., Vien, T. D. (2009a). Swidden Change in Southeast Asia: Understanding Causes and Consequences. Human Ecology. doi:10.1007/ s10745-009-9245-2.

Mertz, O., Leisz, S., Heinimann, A., Rerkasem, K., Thiha, Dressler, W., Cu, P. V., Vu, K. C., Schmidt-Vogt, D., Colfer, C. J. P., Epprecht, M., Padoch, C., Potter, L. (2009b). Who Counts? The Demography of Swidden Cultivators. Human Ecology. doi:10.1007/s10745-009-9249-y.

Myint, H. (1973). The Economics of the Developing Countries, 4th ed, Hutchinson, London.

Nguyen Ngoc (2002). Some Problems Relating to Forestland and Villages in the Mountainous Area of Quang Nam. In National Center for Social and Human Sciences, Some Ideas Related to Socio-economic Development for Indigenous Villages in the Central Highlands. Social Science, Hanoi, pp. 353-372.

Nguyen, T. D. (2005). Culture, society and people in the central highlands (Van Hoa, Xa Hoi va Con Nguoi Tay Nguyen). Social Science, Ho Chi Minh City.

Nielsen, U., Mertz, O., and Noweg, G. T. (2006). The Rationality of Shifting Cultivation Systems: Labor Productivity Revisited. Human Ecology 34: 201-218. doi:10.1007/s10745-006-9014-4.

Novellino, D., and Dressler, W. (2009). The Role of 'Hybrid' NGOs in the Conservation and Development of Palawan Island, the Philippines. Society and Natural Resources, in press.

Padoch, C., Harwell, E., and Susanto, A. (1998). Swidden, Sawah, and In-Between: Agricultural Transformation in Borneo. Human Ecology 26: 3-20. doi:10.1023/A:1018740615905.

Padoch, C., Coffey, K., Mertz, O., Leisz, S. J., Fox, J., and Wadley, R. L. (2007). The Demise of Swidden in Southeast Asia? Local Realities and Regional Ambiguities. Geografisk TidsskriftDanish Journal of Geography 107: 29-41.

Peluso, N. L. (1996). Fruit Trees and Family Trees in an Anthropogenic Rainforest: Property Rights, Ethics of Access, and Environmental Change in Indonesia. Comparative Studies in Society and History 38: 510-548.

Peluso, N. L. (2005). Seeing Properties in Land Use: Local Territorializations in West Kalimantan, Indonesia. Geografisk Tidsskrift: Danish Journal of Geography 105: 1-16.

Peluso, N. L., and Vandergeest, P. (2001). Genealogies of the Political Forest and Customary Rights in Indonesia, Malaysia, and Thailand. Journal of Asian Studies 60: 761-812. doi:10.2307/2700109.

Potter, L. (1987). Degradation, innovation and social welfare in the Riam Kiwa Valley, Kalimantan, Indonesia. In Blaikie, P., and Brookfield, H. (Eds.), Land Degradation and Society. Methuen, London, pp. 164-176.

Raintree, J. B., and Warner, K. (1986). Agroforestry Pathways for the Intensification of Shifting Cultivation. Agroforestry Systems 4: 39-54. doi:10.1007/BF01834701.

Rambo, A. T. (1998). The composite swiddening agroecosystem of the Tay ethnic minority of the Northwestern Mountains of Vietnam. In Patanothai, A. (Ed.), Land Degradation and Agricultural Sustainability: Case Studies from Southeast and East Asia, Regional Secretariat, The Southeast Asian Universities
Agroecosystem Network (SUAN). Khon Kaen University, Khon Kaen, pp. 43-64.

Rambo, A. T. (2005). Searching for Vietnam: Selected Writings on Vietnamese Culture and Society. Trans Pacific, Melbourne.

Rerkasem, K., and Rerkasem, B. (1995). Montane Mainland SouthEast Asia: Agroecosystems in Transition. Global Environmental Change 5: 313-322. doi:10.1016/0959-3780(95)00065-V.

Rerkasem, K., Lawrence, D., Padoch, C., Schmidt-Vogt, D., Ziegler, A. D., Bruun, T. B. (2009). Consequences of Swidden Transitions for Crop and Fallow Biodiversity in Southeast Asia. Human Ecology. doi:10.1007/s10745-009-9250-5.

Roder, W. (1997). Slash-and-Burn Rice Systems in Transition: Challenges for Agricultural Development in the Hills of Northern Laos. Mountain Research and Development 17: 1-10. doi: $10.2307 / 3673908$.

Roder, W. (2001). Slash-and-Burn Rice Systems in the Hills of Northern Lao PDR: Description, Challenges, and Opportunities. International Rice Research Institute, Los Banos.

Ruthenberg, H. (1980). Farming Systems in the Tropics, 3rd edn., Clarendon, Oxford.

Salemink, O. (2003). Ethnography of Vietnam's Central Highlanders. Routledge, London.

Sather, C. A. (1978). Iban Folk Mycology. Sarawak Museum Journal 26: $81-102$.

Sather, C. A. (1990). Trees and Tree Tenure in Paku Iban Society: The Management of Secondary Forest Resources in a LongEstablished Iban Community. Borneo Review 1: 16-40.

Sather, C. A. (1994). The one-sided one: Iban rice myths, agricultural ritual and notions of ancestry. In Walker, A. (Ed.), Rice in Southeast Asian Myth and Ritual. Contributions to Southeast Asian Ethnography vol. 10. Ohio State University, Columbus, $\mathrm{OH}$, pp. 119-150.

Schmidt-Vogt, D. (1998). Swidden Farming and Fallow Vegetation in Northern Thailand. Geoecological Research 8 Franz Steiner Verlag, Stuttgart.

Schmidt-Vogt, D., Leisz, S., Mertz, O., Heinimann, A., Thiha, Messerli, P., Epprecht, M., Cu, P. V., Vu, K. C., Hardiono, M., Truong, D. M. (2009). An Assessment of Trends in the Extent of Swidden in Southeast Asia. Human Ecology. doi:10.1007/s10745-009-9239-0.

Scott, J. C. (1998). Seeing Like a State: How Certain Schemes to Improve the Human Condition Have Failed. Yale University Press, New Haven.

Seavoy, R. E. (1973). The Transition to Continuous Rice Cultivation in Kalimantan. Annals of the Association of American Geographers 65: 218-225. doi:10.1111/j.1467-8306.1973.tb00920.x.

Spencer, J. E. (1966). Shifting Cultivation in Southeastern Asia. University of California Press, Los Angeles.

Suyanto (1999). Evolution of Indigenous Land Tenure Institutions and Tree Resource Management in Sumatra. Ph.D. dissertation, Tokyo Metropolitan University.

Thongmanivong, S., and Fujita, Y. (2006). Recent Land Use and Livelihood Transitions in Northern Laos. Mountain Research and Development 26: 237-244. doi:10.1659/0276-4741(2006)26 [237:RLUALT]2.0.CO;2.

Uchibori, M. (1984). Transformations of Iban social consciousness. In Turton, A., and Tanabe, S. (Eds.), History and Peasant Consciousness in South East Asia. National Museum of Ethnology, Osaka, pp. 211-234.

$\mathrm{Vu}, \mathrm{K}$. (1986). Some Ideas on Socio-economic Issues in the Central Highlands and the Duties of Social Science. In Some Issues on Socio-economy of the Central Highlands. Social Science, Hanoi.

Wadley, R. L., and Colfer, C. J. P. (2004). Sacred Forest, Hunting, and Conservation in West Kalimantan, Indonesia. Human Ecology 32: 313-338. doi:10.1023/B:HUEC.0000028084. 30742.d0. 
Wadley, R., and Mertz, O. (2005). Pepper in a time of crisis: Smallholder buffering strategies in Sarawak, Malaysia, and West Kalimantan, Indonesia. Agricultural Systems 85: 289-305. doi:10.1016/j.agsy.2005.06.012.

Wibawa, G., Hendratno, S., and van Noordwijk, M. (2005). Permanent smallholder rubber agroforestry systems in Sumatra, Indonesia. In Palm, C. A., Vosti, S. A., Sanchez, P. A., and Ericksen, P. J. (Eds.), Slash-and-Burn Agriculture: The Search for Alternatives. Columbia University Press, New York, pp. $222-232$.
Zen, Z., Barlow, C., and Gondowarsito, R. (2005). Oil Palm in Indonesian Socio-economic Improvement: A Review of Options. Working Paper 11/2005. Department of Economics, Research School of Pacific and Asian Studies, Australian National University, Canberra. (http://rspas.anu.edu.au/economics/publish/ papers/wp2005/wp-econ-2005-11.pdf)

Ziegler, A. D., Bruun, T. B., Lawrence, D., Nguyen, T. L. (2009). Environmental Consequences of the Demise in Swidden Agriculture in Montane Mainland SE Asia: Hydrology and Geomorphology. Human Ecology, this issue. 